\title{
The Line Item Veto Case and the Separation of Powers
}

\author{
Matthew Thomas Kline $†$
}

In Clinton v. City of New York, the Supreme Court struck down the Line Item Veto Act because it upset the finely wrought law-making process provided for in the Constitution's Presentment Clause. This Comment argues that the Court reached the right result in Clinton, but for the wrong reason. The Act gave the President the power to cancel certain budgetary items, thus vesting more law-execution power in the executive. Properly understood, the Act did not expand or alter the President's limited lawmaking veto power, as it is defined in the Presentment Clause. This Comment argues that the Act's reshuffling of power did, however, violate the separation-of-powers principle-one of the core political tenets upon which our government of limited powers rests. This Comment further contends that the Court should not have relied upon even an expansive interpretation of the Presentment Clause to strike down the Act, because as case law and history teach, the clause is directed at curbing the expansion of Congress's power, not that of the President. Rather, the Court should have examined in their full light the fundamental separation-of-powers issues at play. After determining whether the shift in power presented the several indicia of a separation-of-powers violation, the Court should have struck down the Line Item Veto Act on explicit separation-of-powers grounds, thus vindicating the long-term liberty interest that the principle centrally serves to safeguard.

\section{INTRODUCTION}

Dissents often help create a Supreme Court Justice's reputation. They also afford Justices the opportunity to state their views plainly, as polemic

Copyright $\odot 1999$ Califormia Law Review, Inc.

$\div \quad$ Law Clerk to the Honorable Edward R. Becker, Chief Judge, United States Court of Appeals for the Third Circuit; J.D., School of Law, University of Califomia, Berkeley (Boalt Hall), 1999; B.A., University of Califomia, Santa Barbara, 1996. Thanks to Judge William A. Fletcher and Professors Jesse H. Choper, Robert C. Post, and John C. Yoo for their helpful comments. Thanks also to the members of the California Law Review, in particular Gillian Brown, Rebecca Engrav, Julia Fromholz, Alison Howard, Greg Jung, Eric Lode, Tu Phan, and Sam Sankar. Finally. special thanks to my family; Professors Burleigh Wilkins, Dick Flacks, Donna Schuele, and Eleanor Swift; and my eshghu-man, Shadi Azarpour. 
and personal theories do not jeopardize fifth votes. Law professors thus teach Justice Holmes' dissenting opinions in Abrams v. United States ${ }^{1}$ and Gitlow v. New York ${ }^{2}$ as early models of modern American constitutionalism clearly stated. Justice Harlan's dissenting opinion in Plessy $v$. Ferguson ${ }^{3}$ similarly receives praise as a model of judicial integrity and wisdom. Justice Scalia's dissents in Morrison v. Olson ${ }^{5}$ and Mistretta $v$. United States ${ }^{6}$ have yet to receive the same degree of praise-and maybe they never will--but they illustrate his judicial acumen and adherence to principle.

While lonely and ominous, ${ }^{7}$ these two dissents are excellent recent examples of reinvigorated separation-of-powers jurisprudence. Not only do they explicate the theories underlying the separation-of-powers principle, which is crucial to the security of liberty under government, but they also are prescient in their warnings about the Office of the Independent Counsel $^{8}$ and the Federal Sentencing Guidelines Commission. ${ }^{9}$ When delivered in the late $1980 \mathrm{~s}$, it may have been easy to disregard Justice Scalia's warnings that these politically popular inventions of government would pose a threat to liberty. But both the experience with Independent Counsels in recent years ${ }^{10}$ and the burdensome effect the Federal

1. 250 U.S. 616,624 (1919).

2. 268 U.S. 652,672 (1925).

3. 163 U.S. 537,552 (1896).

4. In a recent essay, Richard Primus discusses the "canonicity" of Harlan's Plessy dissent and Holmes' First Amendment dissents, and their "reimaging" by scholars and subsequent courts. See Richard A. Primus, Canon, Anti-Canon, and Judicial Dissent, 1998 Duke L.J. 243, 245 n.14, 288-300.

5. 487 U.S. 654, 697 (1988).

6. 488 U.S. 361,413 (1989).

7. Justice Scalia was the lone dissenter in Morrison and Mistretta, and writing the dissents in these cases earned him the nickname the "Prophet of Doom." See DAvid A. ScHulTZ \& CHRISTOPHER E. Smith, The Jurisprudential Vision of Justice Antonin Scalia 82 (1996); $c f$. Mistretta, 488 U.S. at 427 (Scalia, J., dissenting) ("[I]n the long run the improvisation of a constitutional structure on the basis of cumently perceived utility will be disastrous."); Morrison, 487 U.S. at 702 (Scalia, J., dissenting) ("The context of this statute is acrid with the smell of threatened impeachment.").

8. Justice Scalia said the following about the Independent Counsel:

[The Independent Counsel will] assemble a staff by finding out, presumably, who is willing to put aside whatever else they are doing, for an indeterminate period of time, in order to investigate and prosecute the President or a particular named individual in his administration. The prospect is frightening ... even outside the context of a bitter, interbranch political dispute. . . (How much easier it is for Congress, instead of accepting the political damage attendant to the commencement of impeachment proceedings against the President on trivial grounds-or, for that matter, how easy it is for one of the President's political foes outside of Congress-simply to trigger a debilitating criminal investigation of the Chief Executive under this law.)

Id. at 712-13 (Scalia, J., dissenting).

9. See Mistretta, 488 U.S. at 426-28 (Scalia, J., dissenting).

10. In addition to the millions of dollars spent investigating every comer of President Clinton's personal and political life, recent Independent Counsels have spent millions of dollars investigating and prosecuting many lower-level Clinton administration officials and their associates. These people lack President Clinton's political clout and cannot defend themselves as successfully in the media. Moreover, they lack Clinton's legal defense fund. With mixed results, Independent Counsels during the 
Sentencing Guidelines have had on the federal judiciary and criminal defendants' rights ${ }^{11}$ may make some wish that the Court had heeded Justice Scalia's warnings. In sum, Justice Scalia has repeatedly defended this constitutional principle that is as fundamentally important to liberty, or the protection against tyranny, as is the concept of federalism and the guaranteed, individual constitutional rights, textually expressed and implied. ${ }^{12}$

Given Scalia's previous opinions on the separation of powers, one might wonder why he dissented recently in Clinton v. City of New York. ${ }^{13}$ In Clinton, Scalia concluded that the Line Item Veto Act, ${ }^{14}$ which gave the President the power to cancel certain spending items in duly enacted laws, constituted a proper delegation of power to the President, not violative of the separation of powers. ${ }^{15}$ Yet its title alone suggests that the Act "commingles" distinct powers between the executive and legislative branches in a way that Scalia and the Framers he looks to in his opinions so abhor. ${ }^{16}$ His brethren in the majority accepted a variation of this "commingling" analysis and held that the Act was unconstitutional. They reasoned that the Act upset the delicate law-making process provided for in the Constitution's Presentment Clause because it created an additional step in the process for the President. ${ }^{17}$ The majority did not hold, however, that

Clinton-era have brought multi-million dollar prosecutions for trivial crimes even though many prosecutors familiar with the cases say they would never have brought them. See Matt Bai, The Trials of Mike Espy, NewsweEk, Dec. 14, 1998, at 34; Jane Mayer, The Lover in Jail: In Texas, the Independent Counsel Got the Girl, THE NEw YORKER, Nov. 30, 1998, at 55; David Stout, Prosecution that Spared Espy Leaves a Top Aide in Ruins, N.Y. TIMES, June 6, 1999, at A26.

11. See generally Kate Stith \& José A. Cabranes, Fear of Judging: Sentencing Guidelines in the Federal Courts 1-8 (1998) (cataloguing near uniform failure of Federal Sentencing Guidelines to make sentencing more simple and fair and suggesting that Guidelines be discarded or greatly reformed). See also Sanford H. Kadish, Fifiy Years of Criminal Law: An Opinionated Review, 87 CALIF. L. REv. 943, 981 (1999) ("Nowhere have we failed more disastrously than in our sentencing law and policy.").

12. Cf. Rebecca L. Brown, Separated Powers and Ordered Liberty, 139 U. PA. L. Rev. 1513 (1991) (arguing that separation of powers should he understood and enforced as a structural protection of individual rights).

13. 118 S. Ct. 2091 (1998).

14. Line Item Veto Act, Pub. L. No. 104-130, 110 Stat. 1200 (1996) (codified at 2 U.S.C. §§ 691-692 (Supp. Il 1997)).

15. See Clinton, $118 \mathrm{~S}$. Ct. at 2116 (Scalia, J., concurring in part and dissenting in part).

16. See Mistretta v. United States, 488 U.S. 361, 426-27 (1989) (Scalia, J., dissenting) (relying on the writings of the Framers in his dissent to make his argument for a strict separation of powers).

17. See Clinton, $118 \mathrm{~S}$. Ct. at 2103 ("In both legal and practical effect, the President has amended two Acts of Congress by repealing portions of each. '[R]epeal of statutes, no less than enactment, must conform with Art. I.") (citation omitted). The Presentment Clause provides in pertinent part,

Every Bill which shall have passed the House of Representatives and the Senate, shall, before it become a Law, be presented to the President of the Umited States; If he approve he shall sign it, but if not he shall rctum it, with his Objections to that House in which it shall have originated, who shall enter the Objections at large on their Journal, and proceed to reconsider it. If after such Reconsideration two thirds of that House shall agree to pass the Bill, it shall be sent together with the Objections, to the other House, by which it sball likewise be reconsidered, and if approved by two thirds of that House, it shall become a Law... .

$\cdots$ 
the Act violated the separation of powers. ${ }^{18}$ Justice Kennedy, concurring with the majority, vigorously argued that the Act violated the separationof-powers principle and the liberty interests it protects. ${ }^{19}$ Dissenting on these two points, Justices Scalia, O'Connor, and Breyer found no such infirmities. ${ }^{20}$

This Comment argues that the Line Item Veto Act violated the separation of powers, and that the majority in Clinton v. City of New York should have said so explicitly. Relying on first principles of the separation of powers and examining the majority's Presentment Clause analysis, this Comment advances this thesis by attempting to prove three principal claims.

First, as Justices Scalia and Breyer convincingly argued in their dissents in Clinton, the Line Item Veto Act did not violate the Presentment Clause for the following reasons. The Line Item Veto Act did not upset the delicate law-making process, nor did it allow the President to make law. Rather, the Act delegated power to the President to execute laws, duly enacted by Congress, in a certain way: If Congress enacted a statute subject to the budget reducing provisions in the Line Item Veto Act, the President had the discretionary authority to execute the spending cancellation power envisioned in both duly enacted public laws. This delegation of power, and the law-execution arrangement it envisions, comports with the Presentment Clause and the Court's nondelegation doctrine. ${ }^{21}$

Second, this Comment argues that separation-of-powers considerations drove the correct result in this case, if not explicitly. The line-item veto power raised concerns that the Court's hollow nondelegation doctrine

Every Order, Resolution, or Vote, to which the Concurrence of the Senate and House of Representatives may be necessary (except on a question of Adjoumment) shall be presented to the President of the United States; and before the Same shall take Effect, shall be approved by him, or being disapproved by him, shall be repassed by two thirds of the Senate and House of Representatives, according to the Rules and Limitations prescribed in the Case of a Bill.

U.S. Const. art I, § 7, cl. 2-3.

18. See Clinton, $118 \mathrm{~S}$. Ct. at 2108 (deciding it "unnecessary to consider the District Court's alternative holding that the Act impermissibly disrupts the balance of powers among the three branches of government"') (citation omitted).

19. See id. at 2108-10 (Kennedy, J., concurring).

20. All three agreed that the Line Item Veto Act did not unconstitutionally delegate legislative authority to the President; thus, the Act did not violate the separation of powers. Part IlI of Justice Scalia's opinion, which Justices O'Connor and Breyer joined, makes this point. See id. at 2115-18 (Scalia, J., concurring in part and dissenting in part). Part IIl of Justice Breyer's opinion, which Justices O'Connor and Scalia joined, does so as well. See id. at 2120-23 (Breyer, J., dissenting). Justice Breycr wrote alone, however, when discussing at length the reasons why the Line ltem Veto Act did not violate the principle of the separation of powers. See id. at 2123-31.

21. See generally Saikrishna Bangalore Prakash, Deviant Execurive Lawmaking, 67 GEO. WASH. L. REv. I (1998) (arguing that such a delegation of power is not only constitutional under the Necessary and Proper Clause, but sound public policy). 
seemed ill-equipped to address. ${ }^{22}$ To strike the Line Item Veto Act down on separation-of-powers grounds, however, might have threatened other delegations of legislative power that members of the majority do not find problematic. ${ }^{23}$ Thus, the Court's decision to invalidate the Act based on the Presentment Clause rather than the separation-of-powers principle can be seen as a decision to base the holding on very narrow grounds.

This type of rhetorical move presents problems. While locating its implicit separation-of-powers analysis in the textual, procedural requirements of Article I achieves the right end and may be a function of pragmatic necessity, ${ }^{24}$ it misinterprets the text of that Clause and gives short shrift to the crucial constitutional principles at stake. It also prevents the Court from weighing these first principles of the separation of powers explicitly and determining whether they are upset. As Justice Scalia's dissents in Morrison and Mistretta and the fallout from those cases illustrate, ${ }^{25}$ the separation-of-powers principle serves too important a role in safeguarding liberty for the Court to avoid invoking it by name or creating separation-of-powers precedent explicitly.

Last, in examining Clinton, this Comment argues against the champion of modern separation-of-powers jurisprudence, Justice Scalia. Instead, it sides with one of the modern champions of federalism, Justice Kennedy. ${ }^{26}$ It contends that Justice Kennedy's concurrence in Clinton correctly concluded that the Line Item Veto Act violated the separation of

22. The "nondelegation doctrine" prevents Congress from delegating excessively or indiscriminately its law-making power to other branches of Government. See Yakus v. United States, 321 U.S. 414 (1944). A subset of separation-of-powers jurisprudence generally, the doctrine was last invoked by the Court to strike down an Act of Congress in 1935. See A.L.A. Schechter Poultry Corp. v. United States, 295 U.S. 495 (1935) (striking down congressional grant of law-making power to the President). Parts III.B and Ill.C, infra, argue that the Court has merely paid lip service to this doctrine for the last sixty years-that is, until Clinton.

23. See infra Parts IIL.B and Ill.C.

24. Any separation-of-powers theory must take into account the administrative state in which we live. Until the Court undoes the New Deal and the regulatory revolution of the 1970s on separation-ofpowers grounds, which will likely never happen, the Virginia Framers' famous articulation of the separation of powers, as quoted by M.J.C. Vile, will never be realized. See M.J.C. VILE, CONSTITUTIONALISM AND THE SEPARATION OF Powers 119 (1967) (“"[T]he legislative, executive, and judiciary departments shall be separate and distinct; so that neither exercise the powers properly belonging to the other, nor shall any person exercise the powers of more than one of them at the same time."'). Any separation-of-powers theorist should also recognize that the doctrine has taken on a certain political dimension, one often associated with those on the right. See Jonathan Mahler, The Federalist Capers: Inside Ken Starr's Intellectual Auxiliary, Lingua FrancA, Sept. 1998, at 38, 39 (discussing Justice Scalia's dissent in Morrison v. Olson; describing the Federalist Society, of which Justice Scalia is a member, as an organization including "the nation's most conservative and libertarian legal thinkers"). This Comment argues that a strong separation-of-powers doctrine serves traditionally conservative and liberal agendas equally, because rigorously enforced, the doctrine protects citizens' liberty interests and guaranteed rights in the long run. See infra Part II.

25. See supra notes $7-11$ and accompanying text.

26. See, e.g., City of Boerne v. Flores, 521 U.S. 507 (1997) (Kennedy, J.); ldaho v. Coeur d'Alene Tribe of Idaho, 521 U.S. 261 (1997) (Kennedy, J); United States v. Lopez, 514 U.S. 549, 568 (1995) (Kennedy, J, concurring); see also infra note 298. 
powers; it also asserts that the manner in which he addressed this issue was correct. Justice Kennedy rightly relied on the first principles of the separation of powers rather than on law-making procedures in the Presentment Clause that seemed aimed at checking congressional rather than presidential power.

In advancing these three arguments, this Comment calls for an explicit return to first principles in separation-of-powers cases. For too long, the Court has either looked the other way as Congress delegates large swaths of power to other branches of government, or stretched the text of the Constitution, as in this case, to strike down such delegations. Only an expansive reading of the Presentment Clause makes its text dispositive in this case. The nondelegation doctrine provides an incomplete answer as well because the doctrine is, as explicitly applied in the last sixty years, a dead letter. This Comment argues that in cases in which the separation of powers is at issue, and the text and stare decisis do not squarely control, the Court should base its decision on the first principles of the separation of powers.

This Comment divides its analysis into three Parts. Part I traces the political machinations preceding the Line Item Veto Act, parses the workings of the Act and summarizes the Court's recent holding in Clinton. Part II has two objectives. First, it examines writings of the Framers, and of scholars writing about the Framers, that seem to place the separation of powers at the center of our constitutional system of government. It briefly explores the role the Court should play in securing the divisions among the branches of government. Second, Part II discusses the Supreme Court's separation-of-powers decisions. It identifies both the values the Court vindicates (and fails to vindicate) in these cases and the different indicia of separation-of-powers violations the Court consistently recognizes.

Both of these discussions inform Part III, which examines Clinton $v$. City of New York. This Part first argues that the Presentment Clause violation that the majority found was a red herring; the Line Item Veto Act's law-execution arrangement did not give the President the law-making power the clause carefully circumscribes. As argued later in Part III, the majority's analysis of that issue allowed it to invalidate the Line Item Veto Act without addressing the important separation-of-powers violation. The Part next takes up the argument that the Line Item Veto Act violated the separation of powers. Although the Act did not violate the nondelegation doctrine as currently applied, it did upset the tripartite balance of power among the three branches. This Part finally speculates as to why the majority of the Court chose to ground its holding in the text of the Presentment Clause rather than in the separation of powers. 
In its Conclusion, this Comment suggests that it is Justice Kennedy's lone opinion in Clinton that should be studied in the future. By focusing on the separation-of-powers violation and the liberty interest at stake in the case, he expressed a view that may not have been able to garner five votes but best identified the constitutional infirmities inherent in the Line Item Veto Act. It is this approach that the Court should follow in the future. Thus, it is a concurrence, this time, that is worth long study.

\section{The LINE ITEM Veto CASE ${ }^{27}$}

The Supreme Court's invalidation of the Line Item Veto Act marked the end of a long political and legal struggle to vest line-item veto power in the President. The line-item veto power has long appealed to those in government for a variety of reasons. ${ }^{28}$ Late in most congressional terms, Congress presents the President with large omnibus appropriation bills that include expenditures necessary for the federal government to function. ${ }^{29}$ These bills also include many expenditures that arguably serve only the interests of a few..$^{30}$ The President can do little to respond to these inefficiencies except to lobby the public or Congress to veto bills outright. ${ }^{31}$ Lobbying often proves ineffectual and invoking the veto power might lead to a budget freeze but few lasting, beneficial effects. The solution to these problems, according to proponents of the line-item veto power, comes in affording the President, like many state governors, ${ }^{32}$ the power to strike particular items from omnibus spending bills. ${ }^{33}$

27. In referring to the "Line Item Veto Case," this Comment refers to Clinton v. City of New York, 118 S. Ct. 2091 (1998), the case in which the Supreme Court reached the constitutional questions regarding the Line Item Veto Act, not to Raines v. Byrd, I17 S. Ct. 2312 (1997), the case in which the Court held that six members of Congress did not have standing to challenge the constitutionality of the Act. For a brief discussion of Raines, see infra notes 62-64, 135, and accompanying text.

28. See generally Staff of House Comm. on the Budget, 98Th Cong., The Line Item Veto: AN APPRAISAL I1-12 (Comm. Print 1984) [hereinafter ApPraISAL]; Symposium on the Line Item Veto, 1 Notre DAME J.L. Ethics \& Pub. PoL'Y 157 (1985) (tracing the history of and adding to the debate over the line-item veto). In 1984, the House Committee on the Budget produced a report that neatly summarized the general policy arguments for and against the line-item veto. See APPRAISAL, supra, at 15-18. The text accompanying notes $28-45$ in this Section relies heavily upon this report and the symposium issue mentioned above, which includes more expanded commentary.

29. See APPRAISAL, supra note 28, at 11-12, 15-16.

30. See id. at 17. See generally Stephen Glaizer, The Line Iten Veto: Provided in the Constitution and Traditionally Applied, in Pork Barrels and Principles: The Politics of The Presidential Veto 9 (Charles J. Cooper et al. eds., 1988).

31. See Nelson Lund, Rational Choice at the Office of Legal Counsel, 15 CARDozo L. REv. 437 (1993).

32. See APPRAISAL, supra note 28, at 1 ("'[Forty-three] of our 50 States grant their govemors the right to veto individual items in appropriation bills without having to veto the entire bill."') (quoting President Reagan).

33. See id. at 17. 


\section{A. Arguments for and Against a Presidential Line-Item Veto Power}

\section{Arguments for the Power}

Those long advocating the line-item veto power, in particular presidents, have proclaimed its many benefits. ${ }^{34}$ First, proponents of a strong executive felt the line-item veto would bolster the President's sagging veto power. ${ }^{35}$ They argued it would enable the President to keep an irresponsible Congress in "check," and it would provide a "useful tool of persuasion to the President" when he asked Congress to modify excessive spending bills. ${ }^{36}$

Second, proponents of the line-item veto argued that its power would not upset the separation of powers. Congress could preserve the delicate balance of powers by reversing unwise presidential action through twohouse, two-thirds majority overrides of the President's line-item vetoes. Since Congress gave the President the line-item veto power by statute, it could also deprive the President of that power altogether by repealing the statute. In addition, even if the line-item veto power was vested by constitutional amendment, Congress could galvanize public opposition to lineitem vetoes, or, in the last instance, impeach the President. ${ }^{37}$

Third, proponents of the line-item veto promised that it would result in more efficient government. Policy makers felt that while members of Congress were beholden to local interests and forced to fight for local spending projects to insure their reelection, the President's national office and duties gave him the necessary political shield and incentives to trim the

34. See Peter M. Shane \& Harold H. Bruff, Separation of Powers law 206 (1996) ("Presidents have sought this authority for many years.") Shane and Bruff note that some argue that the line-item veto power is already provided for by the Constitution:

The argument is based on the fact that the anti-evasion clause of Article 1 says that, in addition to "Bills," every "Order, Resolution, or Vote" for which the concurrence of the two houses is necessary must be presented to the President for his possible veto. That would include many internal portions of bills.

Id. at 210. Shane and Bruff, however, go on to note that Professors Laurence Tribe and Philip Kurland reject this reading as contrary to a "commonsense reading of the constitutional text' and historical evidence." Id. (citation omitted). Shane and Bruff conclude that not all agree on the matter. See id. (citing Michael B. Rappaport, The President's Veto and the Constitution, 87 Nw. U. L. Rev. 735 (1993) (rebutting arguments for an existing line-item veto power); J. Gregory Sidak \& Thomas A. Smith, Four-Faces of the Item Veto: A Reply to Tribe and Kurland, 84 Nw. U. L. REv. 437 (1990)). These debates were repeated in the literature after the passage of the 1996 Line ltem Veto Act. See Prakash, supra note 21, at 5 n.22 (collecting this literature).

35. See APPRAISAL, supra note 28, at 15 (describing the waning nature of the President's veto power given the enormity of the bills presented to him and his concomitant inability to have a direct effect on discrete pieces of Iegislation).

36. Id. at 17.

37. See id. at 15-17. Although impeachment may seem an extreme remedy, one could imagine that the House might consider a line-item veto decision, used as a payback for illegal campaign contributions, a High Crime or Misdemeanor. 
fat, so to speak. ${ }^{38}$ In doing so, the President would also be able to help reduce the crushing budget deficit, which owed much of its heft to porkbarrel politics. ${ }^{39}$

\section{Arguments Against the Power}

Those opposed to the line-item veto advanced two main lines of argument. First, they argued that it violated the separation of powers. Critics felt the line-item veto power impermissibly vested uncertain power in the President, that it "shift[ed] control of the purse strings of the Government from Congress to the Executive,"40 that it allowed the President to substitute his policy judgments for those of the Congress, and that it "would practically destroy the only power Congress now has over the President other than impeachment."4l Moreover, because the power violated the Constitution by violating the separation of powers and thus could not be created by statute, critics argued that the costly and difficult constitutional amendment process would be required to give the President the power.

Second, opponents argued that the line-item veto was not the panacea proponents promised it to be. They argued that the line-item veto would make members of Congress less responsible to the public because members could let "the President take the heat for vetoing fiscally irresponsible yet district-pleasing projects. ${ }^{324}$ Opponents also doubted that the line-item veto would help reduce government largesse, ${ }^{43}$ serve to balance the budget, ${ }^{44}$ or make the government work more efficiently. ${ }^{45}$

38. See, e.g., Clinton v. City of New York, 118 S. Ct. 2091, 2107 (1998) ("Many members of both major political parties who have served in the Legislative and the Executive Branches have long advocated the enactment of [line-item veto] procedures for the purpose of "ensur[ing] greater fiscal accountability in Washington."' (quoting H.R. CoNf. REP. No. 104-491, at 15 (1996))). In Clinton, the Court also noted that former President and Chief Justice Taft felt that a line-item veto power would help restrain government expenditure, but that such a power was unconstitutional. See id. at 2104 n. 30 , 2107 n.4I (citing William Howard Taft, The Presidency: 1Ts Duties, ITs Powers, Its OPPORTUNITIES AND ITS LIMITATIONS 11,21 (1916)).

39. See APPRAISAL, supra note 28, at 14. I6. Eighteenth-century European political theorists, who wrote about the separation of powers and influenced the Framers, envisioned the "king" playing such a role: They envisioned the executive "ris[ing] above party turmoil to embody a disinterested notion of the public good." JACK N. RaKove, ORIGiNal MEANings 248 (1996) (citing Viscount Bolingbroke, The IdeA of a Patriot King (1738)).

40. APPRAISAL, supra note 28 , at 18 .

41. Id. at 15 .

42. Id. at 17 .

43. See id. at 16-17.

44. Perhaps owing to who the President was in 1984, opponents making the claim that the line-item veto would not help reduce the budget deficit rested one of their arguments upon the assumption that it was unlikely that the President would strike line items providing for tax breaks or defense spending, some of the primary causes of the budget deficit. See id. at 5-6, 16-17. Limited experience has taught the opposite. It was President Clinton's decision to line-item veto a tax break to farmers that gave rise to the case that is the subject of this Comment. See Clinton v. City of New York, 118 S. Ct. 2091, 2096. 2096 n.5 (1998). Moreover. of the 82 spending cancellations President Clinton 


\section{B. The Line Item Veto Act}

For years, versions of a line-item veto bill and several proposed constitutional amendments languished in Congress and in the states. ${ }^{46}$ Then in 1994, soon-to-be Speaker of the House Newt Gingrich made the line-item veto a part of his "Contract With America." ${ }^{47}$ In April 1996-by statute, and not constitutional amendment-Congress passed the Line Item Veto Act, and President Clinton signed it into law. ${ }^{48}$

Subject to certain procedures and limitations on discretion, the Line Item Veto Act of 1996 gave the President the nominal power to line-item veto three types of budgetary provisions. The Act gave the President the power to "cancel in whole... (1) any dollar amount of discretionary budget authority; (2) any item of new direct spending; or (3) any limited tax benefit." 49 The cancellation would rescind the dollar amount appropriated to discretionary budget items and prevent spending and tax benefit items "from having legal force or effect." 50 Before canceling items, however, the Act required the President first to determine that each specific cancellation would "(i) reduce the Federal budget deficit; (ii) not impair any essential Government functions; and (iii) not harm the national interest."st The Act further required that the President consider each item's purposes and legislative history. ${ }^{52}$ The Act afforded the President five calendar days to cancel any items after they were enacted into law. ${ }^{53}$ The

made pursuant to his power under the Line Item Veto Act, the only cancellation and veto that Congress overrode was "the cancellation of 38 military construction spending items." Id. at $2102 \mathrm{n} .24$ (citing Pub. L. 105-159, 112 Stat. 19 (1998)).

45. See APPRAISAL, supra note 28 , at $16-17$.

46. See id. at 1, 11-12; Alan Morrison, The Line ltem Veto: Both Parties Want lt, but Is It Constitutional? Yes: Unbundling Omnibus Bills Won't Work, 81 A.B.A. J. 46, 46 (1995).

47. See Republican Contract with America (visited Apr. 8, 1998) <http://www.house.gov/house/ Contract/CONTRACT.html > ("Within the first 100 days of the 104th Congress, we shall bring to the House Floor .... a legislative line-item veto to restore fiscal responsibility to an out-of-control Congress. ...").

48. See Congressional Information Service, CiS/AnNual 1997: Legislative Histories OF U.S. Public Laws 75 (1997).

49. 2 U.S.C. § 691(a) (Supp. II 1997).

50. Id. $\S 691 \mathrm{e}(4)(\mathrm{B})(\mathrm{i})$; see also id. $\S 691 \mathrm{e}(4)(\mathrm{A})$-(C) (legislative definition of cancellation).

51. Id. $\S 691(\mathrm{a})(3)(\mathrm{A})$.

52. See id. $\$ 691(\mathrm{~b})$.

53. See id. $\S 691(\mathrm{a})(3)(\mathrm{B})$. The fact that the President cancels items after they have been signed into law should be highlighted. See id. $\S 691$ (a). The original Senate version of what became the Line Item Veto Act took a different tack. It had tbe effect of dividing each appropriations bill that Congress passed into as many separate bills as there were items. See S. 4, 104th Cong. (1996). Presented with these separate bills, the President could use his explicitly provided Article $1, \S 7$ power to veto individual bills, or items, which he found objectionable. See SHANE \& BRUFF, supra note 34, at 210. While this process may seem more burdensome than the euacted process, it might have mollified the majority in this case, which seemed concemed with following the exact procedures set forth in Article 1, § 7. See Clinton v. City of New York, 118 S. Ct. 2091, 2108 (1998); cf. Shane \& BrufF, supra note 34, at 210 (questioning whether splitting all provisions in bills into separate bills would be unconstitutionally cumbersome) (citing The Line Item Veto, 81 A.B.A. J. 46, 46-47 (June 1995)). In his 
President had to memorialize his cancellation decisions in a "special message" to Congress..$^{54}$ Upon Congress's receipt of the President's special message, the cancellations would take effect ${ }^{55}$ while the uncanceled parts of the bill would be duly enacted.

Congress did not, however, leave itself powerless to reject the President's line-item cancellations. Congress retained the power to pass a "disapproval bill" by a simple majority; this would render the cancellations in the President's special message null and void. ${ }^{56}$ The Act also provided that disapproval bills were subject only to the President's Article I veto and not line-item cancellation as provided for in the Line Item Veto Act. ${ }^{57}$ In addition, Congress could exempt particular bills from the Line Item Veto Act or repeal the Line Item Veto Act altogether. ${ }^{58}$ The last means of protection that Congress created for itself were expedited review and standing provisions. ${ }^{59}$ These provisions may have been inserted to appease those members hesitant to vote for the potentially unconstitutional bill. By their terms, however, the provisions allowed members of Congress to obtain expedited Supreme Court review and to challenge the validity of the Act. ${ }^{60}$ Thus, if Congress was giving away too much of its power, the courts could soon fix matters. ${ }^{61}$

\section{The Line Item Veto Act's Reception in the Courts}

The day the Line Item Veto Act took effect in January 1997, six members of Congress who had voted against it used the Act's standing

dissent, Justice Breyer argued that dividing appropriations bills into thousands of separate appropriations bills for the President to approve of or to veto individually would be impractical but nonetheless constitutional. In fact, he stated that the Line Item Veto Act chose "a particular novel means to achieve this same, constitutionally legitimate, end." Clinton, $118 \mathrm{~S}$. Ct. at 2119 (Breyer, J., dissenting) (emphasis deleted).

54. 2 U.S.C. $\$ 691(\mathrm{a})(3)(B)$ (Supp. II 1997).

55. See id. $\$ 691 \mathrm{~b}(\mathrm{a})$.

56. See id. $\$ \S 691 \mathrm{~b}(\mathrm{a}), 691 \mathrm{~d}, 691 \mathrm{e}(6)$. Congress could also, of course, override a veto of the disapproval bill. See U.S. CoNsT. art. 1, § 7, cl. 2.

57. See 2 U.S.C. § 691(c). If, however. Congress let the cancellations stand, the Line Item Veto Act insured that the money saved would be set aside to help reduce the budget deficit. For a description of this "lock box," "pay-as-you-go" system, see Prakash, supra note 21, at 9-10, and accompanying notes.

58. It should also be noted that because a President would doubtless oppose forfeiting such cancellation power, two-thirds of Congress might have been needed to strip the President of such power because he would use his Article I veto power to challenge such an enactment. See U.S. CoNST. art. $1, \S 7, \mathrm{cl} .2$ (providing that President's veto can be overridden by two-thirds vote in each House of Congress).

59. See 2 U.S.C. § 692(a)(1) (authorizing "[a]ny Member of Congress or any individual advcrsely affected" by the Act to challenge its constitutionality); id. $\$ \S 692(a)$-(c) (providing for direct and expedited review by district court and for direct and expedited appeal to Supreme Court).

60. See supra note 54.

61. The Act did not contain a severability clause. See H.R. CoNF. REP. No. 104-491, at 17, 41 (1996) (removing severability clause without explanation). Thus, the Act would stand or fall in its entirety when reviewed by the Court. 
provision to challenge its constitutionality. ${ }^{62}$ Finding that the six members had standing, the district court ruled in their favor and held that the Act violated the Presentment Clause, the nondelegation doctrine and the separation of powers generally. ${ }^{63}$ On expedited review in June 1997, the Supreme Court vacated the district court's judgment. The Court held that the six members of Congress lacked Article III standing because they had failed to "allege[] a sufficiently concrete injury...." Opt Opponents of the Act, however, did not have to wait long for their day in court.

In August 1997, President Clinton made two cancellations that would become the subject of Clinton $v$. City of New York. He canceled a direct spending itein provided for in section 4722(c) of the Balanced Budget Act of $1997,{ }^{65}$ and he canceled two limited tax benefit items provided for in section 968 of the Taxpayer Relief Act of $1997 .{ }^{66}$ Opponents of the Line Item Veto Act finally had their Article III injuries-in-fact. The City of New York, health care providers, and two unions challenged the cancellation of section 4722(c). ${ }^{67} \mathrm{~A}$ farmers' cooperative and one of its individual members filed separate suits against the President and federal officials challenging the cancellation of section $968 .^{68}$ The district court consolidated the two cases and, finding standing, once again held that the Line Item Veto Act was unconstitutional. ${ }^{69}$ The court held that the cancellations violated the Constitution's Bicameralism and Presentment Clauses because the President had both altered the language of laws enacted by Congress, and he had effected unilateral repeals of duly enacted laws. ${ }^{70}$ In the alternative, the court held that the Act "impermissibly disrupt[ed] the balance of powers anong the three branches of government."71

The Supreme Court heard the appeal on expedited review. ${ }^{72}$ The Court held that all the plaintiffs had Article III standing because in losing the canceled benefits they suffered an actual harm, "likely be redressed by a

62. See Byrd v. Raines, 956 F. Supp. 25 (D.D.C. 1997), prob. juris. noted, Raines v. Byrd, 520 U.S. 1194 (1997), vacated, Raines v. Byrd, 117 S. Ct. 2312 (1997). Many scholars entered the fray as well by examining the Act's constitutionality. See Prakash, supra note 21, at $5 \mathrm{n} .22$ (cataloguing the literature on both sides of the debate).

63. See Byrd, 956 F. Supp. at 33-36.

64. Byrd, $117 \mathrm{~S}$. Ct. at 2322. The fact that Congress extended standing to challenge thc constitutionality of the Act to "[a]ny Member of Congress," 2 U.S.C. $\$$ 692(a)(1), did not matter to the Court, which was concerned with honoring the jurisdictional limits imposed by Article 111. See Raines, 117 S. Ct. at 2318.

65. See Clinton v. City of New York. 118 S. Ct. 2091, 2095-96 (1998).

66. See id.

67. See id. at 2096-97.

68. See id.

69. See New York v. Clinton, 985 F. Supp. 168, $177-82$ (D.D.C. 1998).

70. See id. at 178-79

71. Id. at 179.

72. See Clinton, 118 S. Ct. at 2095. 
favorable decision." ${ }^{73}$ Turning its attention to the merits, the Court held that the Line Item Veto Act was unconstitutional because it violated the Presentment Clause. ${ }^{74}$ Citing INS v. Chadha, ${ }^{75}$ the majority held that the Line Item Veto Act upset the "single, finely wrought and exhaustively considered" "constitutional procedure for the enactment of law. ${ }^{76}$ The majority reasoned that because cancellation constituted an amendment or a repeal of a portion of a statute, the Act impermissibly gave "the President the unilateral power to change the text of duly enacted" laws. ${ }^{77}$ The majority based this conclusion on the difference between the normal veto, which both takes place before a bill becomes a law and affects a bill in toto, and the cancellation power, which the President employs after the bill has been signed into law and which affects only certain provisions in the new law. The rnajority held that these two differences gave the President a repeal power, or an extra role in the law-making process, that the Framers had implicitly rejected when they crafted the heavily debated Presentment Clause. ${ }^{78}$ The Court also rejected government arguments characterizing the cancellation power as a law-execution power rather than a law-making power, which would not be subject to the Presentment Clause. The Court further held that the cancellation power could not be understood as the President's mere exercise of properly delegated discretionary authority or of his office's traditional statutory authority to decline to spend appropriated funds or implement specified tax benefits. ${ }^{79}$

In the dissenting portions of their opinions, Justices Scalia and Breyer (whom Justice O'Connor joined) addressed these two government arguinents. The dissenters agreed that the presidential cancellation power did not implicate the Presentment Clause; instead, the power merely amounted to a constitutional delegation of discretionary authority. ${ }^{80}$ They analogized the cancellation power to several other instances in which Congress,

73. Id. at 2102. Justices Scalia and $O^{\prime}$ Connor did not believe that the farmers' collective or its individual members had Article III standing to challenge the cancellation of the two tax benefits. See id. at 2111-15 (Scalia, J., concurring in part and dissenting in part, joined by O'Connor, J.). Justices Scalia and O'Connor did find, however, that the New York plaintiffs had standing to challenge the cancellation of an item of direct spending, which would have saved plaintiffs from incurring tax liability. See id. at 2115.

74. See id. at 2108 (holding that a Public Law " "as modified by the President" pursuant to the Line Item Veto Act "is surely not a document that may 'become a law' pursuant to the procedures designed by the Framers of Article $1, \S 7$, of the Constitution").

75. 462 U.S. 919, 951 (1983) (holding that the one-house legislative veto violated the Presentment Clause because it removed the President and his possible veto from the law-making process).

76. Clinton, 118 S. Ct. at 2104 (quoting INS v. Chadha, 462 U.S. 919, 951 (1983)).

77. Clinton, 118 S. Ct. at 2107.

78. See id. at 2105-08.

79. See id.

80. See id. at 2115-19 (Scalia, J., concurring in part and dissenting in part); id. at 2118-23 (Breyer, J., dissenting); see also supra note 20. 
without objection, granted the executive or even the judiciary such discretionary power. They could find no reason why the Line Item Veto Act should be treated differently. ${ }^{81}$ Justice Scalia further argued that in taking advantage of the cancellation power, the President merely exercised his traditional statutory authority to dechne to spend..$^{82}$

Although the majority found it unnecessary to reach the separation-ofpowers issue that the district court reached, ${ }^{83}$ Justice Breyer explicitly considered the separation-of-powers principles that were implicated before he concluded that the Act was constitutional. ${ }^{84}$ Justices Scalia and O'Connor reached the same conclusion but did not join the separation-of-powers portion of Justice Breyer's opinion. ${ }^{85}$ As mentioned above, Justice Kennedy wrote a pointed concurrence specifically countering Justice Breyer's separation-of-powers analysis. ${ }^{86}$ Justice Kennedy argued that the Line Item Veto Act aggrandized the President's power, encroached on the legislature's law-making function and allowed the President to favor certain groups over others with selective cancellations. ${ }^{87}$ In sum, he concluded, the Act "compromise[d] the political liberty of our citizens, liberty which the separation of powers seeks to secure." 88

\section{$* * *$}

Before analyzing the Court's opinions in Clinton, the next Part examines the values and principles underlying the separation of powers. Given that the majority's Presentment Clause analysis and Justice Kennedy's separation-of-powers reasoning led to the same, (I argue) correct conclusion, it is important to this Comment's main thesis-that Justice Kennedy's approach and result were the correct ones in difficult separation-of-powers cases-to justify a more explicit separation-ofpowers approach and result. To do so, Part II shows the importance of the

81. See Clinton, 118 S. Ct. at 2115-17 (Scalia, J., concurring in part and dissenting in part); id. at 2121-23 (Breyer, J., dissenting).

82. See id. at 2116-17 (Scalia, J., concurring in part and dissenting in part).

83. See id. at 2108.

84. See id. at 2123-31 (Breyer, J., dissenting).

85. See id. at 2116 (Scalia, J., concurring in part and dissenting in part, joined by O'Connor, J.). They likely did not join Part IV of Breyer's opinion because it defends a fuuctional approach to separation-of-powers jurisprudence. See id. at 2120 (Breyer, J., dissenting) ("[W]e are to interpret nonliteral Separation of Powers principles in light of the need for 'workable government."') (citation omitted). Justice Scalia would almost certainly disagree with such an approach. See infra notes 127-29 and accompanying text. It is harder to predict Justice $O^{\prime}$ Connor's separation-of-powers stance given that she has voted with the majority in formalist cases-Chadha and Bowsher-and functionalist cases-Morrison and Mistretta. See infra Part II (discussing these four cases and the two formalist and functionalist approaches).

86. See Clinton, $118 \mathrm{~S}$. Ct. at 2108 (Kennedy, J., concurring) ("1 write to respond to my colleague Justice Breyer, who observes that the statute does not threaten the liberties of individual citizens, a point on which 1 disagree.").

87. See id. at 2108-10.

88. Id. at 2110 . 
separation-of-powers principle in our constitutional framework. It also discusses the Court's decisional law in this area. Building on these points, Part III argues that the Line Item Veto Act violated the separation of powers and that the majority wrongly relied upon the Presentment Clause to strike down the Line Item Veto Act.

III

\section{The Separation of Powers: In Principle and in Practice}

\section{A. Introduction}

The separation-of-powers principle does real work in our constitutional structure. The Court invokes the principle in political battles among itself, Congress, and the President. ${ }^{89}$ It also invokes the principle to strike down laws that threaten the balance of power between the three branches of the federal government. It does so even if those statutes receive enormous popular support or seem necessary to cure the economic ills of a nation crushed by debt. ${ }^{90}$ Yet for all the work that the principle does, the Court's separation-of-powers jurisprudence selectively invokes the theories that underlie the principle. ${ }^{91}$ The Court's jurisprudence can also be

89. See, e.g., United States v. Nixon, 418 U.S. 683 (1974) (upholding subpoena that required President Nixon to produce tapes and documents relating to his actions as President; rejecting claim of absolute executive privilege).

90. For example, in City of Boeme v. Flores, 117 S. Ct. 2157 (1997), the Court struck down the Religious Freedom Restoration Act of 1993, 42 U.S.C. $\$ 2000$ bb et seq. (1994), even though a "legion of divergent interest groups" lobbied for the RFRA, and it "gamered virtually unanimous support in both the House and the Senate." Daniel O. Conkle, The Religious Freedom Restoration Act: The Constitutional Significance of an Unconstitutional Statute, 56 MoNr. L. REv. 39, 39 (1995). Similarly, in Bowsher v. Synar, 478 U.S. 714 (1986), the Court invalidated the Balanced Budget and Emergency Deficit Control Act of 1985, Pub. L. No. 99-177, 99 Stat. 1037 (codified at 2 U.S.C. $\$ 901$ et seq. (1995)), which many believed was necessary to protect the economic health of the nation. See E. Donald Elliot, Regulating the Deficit After Bowsher v. Synar, 4 YALE J. ON REg. 317 (1987). For a good example of the Court's hesitancy to strike down such an important statute, see Bowsher, 478 U.S. at 736 (Stevens, J., concurring) ("When this Court is asked to invalidate a statutory provision that has been approved by both Houses of the Congress and signed by the President, particularly an Act of Congress that confronts a deeply vexing national problem, it should only do so for the most compelling constitutional reasons.").

91. See Charles Fried, Order and law: Arguing the Reagan Revolution-A FIRSTHAND ACCOUNT 158-70 (suggesting that the Court adopted the Reagan Administration's rigorous conception of the separation of powers in Chadha and Bowsher, but that the Court balked at the opportunity to apply this new rigor to the widely popular Independent Counsel law; concluding that the new theory that the Administration was advancing was derailed in Morrison, and suggesting that the ground lost could not be retrieved); Stephen L. Carter, From Sick Chicken to Synar: The Evolution and Subsequent De-Evolution of the Separation of Powers, 1987 B.Y.U. L. REv. 719, 720-25, 775-80 (tracing the Court's contradictory separation-of-powers jurisprudence and arguing for a more historical approach); see also Morrison v. Olson, 487 U.S. 654, 725-26 (1988) (Scalia, J., dissenting) (arguing that the majority treated the Court's decision in Humphrey's Executor v. United States, 295 U.S. 602 (1935) shoddily, but noting ironically that Humphrey's Executor had similarly gutted the Court's careful decision in Myers v. United States, 272 U.S. 52 (1926)).

The ebb and flow of the Court's jurisprudence in this area may have something to do with the fact that each branch's powers seemingly have evolved over time and that it is difficult for the 
understood as unmindful of principle altogether. ${ }^{92}$ To see such inconsistency, one only need compare Morrison $v$. Olson, ${ }^{93}$ in which the Court upheld a congressional statute providing that the judiciary would monitor independent prosecutions within the executive branch, with Bowsher $v$. Synar, ${ }^{94}$ in which the Court invalidated a balanced budget statute because an officer subject to congressional removal played a role in administering the act. The former decision certainly allowed commingling of governmental powers, while the latter allowed virtually none..$^{95}$

Two primary tensions seem responsible for the muddled state of separation-of-powers law. The first dispute is most explicitly taken up by academics and involves the question whether the Court should entertain separation-of-powers challenges in the first place. ${ }^{96}$ The second dispute evidences itself in the Court's decisional law and centers on the level of scrutiny courts should apply in separation-of-powers cases. ${ }^{97}$ Underlying both of these discussions is the political theory, envisioned by the Framers, upon which the separation-of-powers principle rests. ${ }^{98}$ The next three Sections examine the historical underpinnings of the separation-of-powers principle, the academic debate regarding judicial review in this area and the Court's case law in this area.

contcmporary Court to respond to these changes. See SHANE \& BRUFF, supra note 34, at 35. The rise of the administrative state comes to mind first when thinking of evolutions within and among branches that the courts and scholars have had difficulty squaring with original practices and what was once established separation-of-powers jurisprudence. The growing power of the administrative state has spurred great debate regarding the role of the President, Congress, and the courts in responding to this seemingly new "Fourth Branch." See, e.g., Steven G. Calabresi \& Saikrishna B. Prakash The President's Power to Execute the Laws, 104 Y ALE L.J. 541 (1994); Lawrence Lessig \& Cass R. Sunstein, The President and the Administration, 94 Colum. L. Rev. 1 (1994).

92. In Morrison, Justice Scalia criticized the Court for deciding separation-of-powcrs cases on an ad hoc basis, rather than reasoning from first principles laid down by the Framers. See 487 U.S. at 734 (Scalia, J., dissenting). In Mistrettu, he wrote,

Today's decision follows the regrettable tendency of our recent separation-of-powers jurisprudence ... to treat the Constitution as though it werc no more than a generalized prescription that the functions of the Branches should not be commingled too much-how much is too much is to be determined, case-by-case by this Court. The Constitution is not that.

488 U.S. at 426 (Scalia, J., dissenting).

93. 487 U.S. 654 (1988).

94. 478 U.S. 714 (1986).

95. One way to distinguish these two cases, suggested by Dean Daniel B. Rodriguez, is that Congress, the strongest of the three branches, aggrandized its powcr at the expense of the executive in Bowsher, but not in Morrison. By contrast, in Morrison Congress expanded the power of the judiciary, the weakest branch, at the expense of the executive. This case, in which Congress expanded the President's power at its own expense, falls somewhere between the two.

96. See infra Part 11.C.

97. See infra Part II.D.

98. See infra Part II.B. 


\section{B. The First Principles Underlying the Separation of Powers}

At the Framing, powers were separated among the branches of federal government not because the multiple divisions provided for the most efficient form of governance. ${ }^{99}$ Instead, initially conceived of as a bulwark against centralized power, this internal, structural constraint on government served to secure liberty for individuals. ${ }^{100}$

The Framers' experience in the late Colonial period informed this desire to protect liberty from the hands of centralized power. ${ }^{101}$ As Gordon Wood and Jack Rakove note in their histories of the period, many early proponents of a trifurcated government argued for separation of powers by citing the myriad abuses of power by unchecked royal governors before the Revolution and early all-powerful state legislatures that ruled between the Revolution and the Framing. ${ }^{102}$ Unhappy with these pre- and postRevolutionary arrangements, the Framers separated government along multiple axes, and gave these units of government the incentive and the means to check one another. ${ }^{103}$ In doing so, the Framers first divided power

99. In INS v. Chadha, Chief Justice Burger recognized that "[t]he choices we discern as having been made in the Constitutional Convention impose burdens on governmental processes that often seem clumsy, inefficient, even unworkable, but those hard choices were consciously made by men who had lived under a form of government that permitted arbitrary governmental acts to go unchecked." 462 U.S. 919, 959 (1983). In his famous dissent in Myers v. United States, Justice Brandeis wrote, "The doctrine of the separation of powers was adopted by the Convention of 1787, not to promote efficiency but to preclude the exercise of arbitrary power. The purpose was, not to avoid friction, but, by means of inevitable friction incident to the distribution of the governmental powers among three departments, to save the people from autocracy." 272 U.S. 52, 293 (1926) (Brandeis, J., dissenting); see also Morrison, 487 U.S. 654, 697 (1988) (Scalia, J., dissenting); John C. Yoo, The Judicial Safeguards of Federalism, 70 S. CAL. L. REv. 1311, 1404 (1997) ("The Framers believed this deliberate inefficiency to be necessary in order to protect liberty.").

100. Justices Kennedy and Breyer recognized as much in Clinton v. City of New York, as have Justice Scalia and the Court elsewhere. See Clinton, 118 S. Ct. at 2109 (Kennedy, J., concurring); id. at 2131 (Breyer, J., dissenting); Morrison, 487 U.S. 654, 727 (1988) (Scalia, J., dissenting) (noting that when discussing the separation of powers "[i]n No. 47 of The Federalist, Madison wrote that '[n]o political truth is certainly of greater intrinsic value, or is stamped with the authority of more enlightened patrons of liberty"); Bowsher v. Synar, 478 U.S. 714, 730 (1986) ("The Framers recognized that, in the long term, structural protections against abuse of power were critical to preserving liberty."). Rebecca Brown writes that structural constraints in the Constitution, such as the separation of powers and our limited version of majoritarian democracy, protect liberty by serving as tyranny minimizing devices. See Rebecca L. Brown, Accountability, Liberty, and the Constitution, 98 Colum. L. REv. 531, 535, 565 (1998). Her scholarship proceeds from the first principle that the Framers' notion of the primary goal of government was to "protect the hiberty of the people from government invasion." Id. at 535. All government structures then, she argues-from the separation of power to popular participation in representative democracy-were designed to serve that end. See id. at 535-38, 570-77.

101. See Brown, supra note 100 , at 535-38.

102. See Rakove, supra note 39, at 249-50; Gordon S. Wood, The Creation of the AMERICAN REPUBLIC $1776-1787$, at 154-61 (1969).

103. When framing the Constitution, Madison gave us his "policy of supplying, by opposite and tival interests, the defect of better motives." THE FEDERALIST No. 51, at 322 (James Madison) (Cliuton Rossiter ed., 1961). This policy unseated the power hungry executive and legislative hegemonies that preceded the Framing. 
between the formerly all-powerful states and the federal government. The Framers next divided power among the three branches, ${ }^{104}$ and made these branches, and the federal government that they comprised, generally accountable to the citizenry by providing for regular elections. ${ }^{\text {105 }}$

In drafting the Constitution, the Framers did not, however, explicitly define whether or to what degree the Supreme Court would safeguard these multiple divisions of power. Scholars have wasted no ink in responding to this lack of clarity; moreover, in their written opinions several Justices have taken up the issue explicitly. The next Section briefly canvasses this unresolved constitutional question.

\section{The Supreme Court's Role in Separation-of-Powers Disputes}

As the head of a co-equal branch in our tripartite system, the Supreme Court has often played a crucial role in securing the separation of powers and acting as a check on its fellow branches of government. In doing so, the Court has arguably risked overstepping its own bounds of powers. The Court, however, can also be seen as having protected the individual liberty interests, in which the Framers were so interested, by ensuring that the units of government operate within their defined fields of power. ${ }^{106}$ In choosing to police the boundaries of the separation of powers, the Court, under this second view, guards against intrusion upon individual liberties in the long run by guarding in the short run against the "tyrannical concentration of all the powers of government in the same hands." 107

104. Madison called the separation of powers among the branches "a first principle of free govemment." WoOD, supra note 102, at 152 (quoting James Madison, PhiladelPHia National GazeTte, Feb. 6, 1792, in 6 The Writings of JAMEs MAdison 91 (Gaillard Hunt ed., 1900-10)).

105. See Brown, supra note 100 , at 558-71.

106. See Clinton, 118 S. Ct. at 2109 (Kennedy, J., concurring). Kennedy writes,

In recent years, perhaps, we have come to think of liberty as defined by that word in the Fifth and Fourteenth Amendments and as illuminated by the other provisions of the Bill of Rights. The conception of liberty embraced by the Framers was not so confined. They used the principles of separation of powers and federalism to secure liberty in the fundamental political sense of the term.... In this vision, liberty demands limits on the ability of any one Id. branch to influence basic political decisions.

107. The Federalist No. 48, supra note 103, at 313 (James Madison). Two good examples of instances in which the Court played this role are a separation-of-powers case involving the Nixon Administration and the Court's firm stance in Marbury v. Madison, 5 U.S. (1 Cranch) I37 (1803). In both of these cases, the Court guarded against the "tyrannical concentration" of power in one branch of government. In the Nixon Administration case, the Court held that the President could not refuse to honor a lawful subpoena that a federal trial court had issued demanding production of the Watergate tapes. See United States v. Nixon, 418 U.S. 683 (1974). Had the President been able to ignore this subpoena and frustrate the underlying criminal investigation and pending prosecution, he would have achieved the power enjoyed by pre-Revolutionary royal governors: He would have stood above the law. Cf. Clinton v. Jones, $117 \mathrm{~S}$. Ct. 1636 (1997) (holding that the President has no executive immunity for acts unrelated to carrying out his office). But cf. Nixon v. Fitzgerald, 457 U.S. 731, 766 (1982) (White, J., dissenting) (arguing that in holding that the President has absolute immunity for his official acts, the majority "places the President above the law," and "revert[s] to the old notion that the King 
There is an argument to be made that the Framers envisioned the Court playing this role of actively policing power disputes among the three branches. Such intent arguably can be discerned from the political theory underlying our Constitution. In Federalist No. 51, Madison explained that in framing our constitutional structure, "[a]mbition ... [was] made to counteract ambition." 108 The Constitution "contriv[es] the interior structure of the government as that its several constituent parts may, by their mutual relations, be the means of keeping each other in their proper places." 109 Understanding human nature as power-maximizing and less than angelic, ${ }^{110}$ Madison concluded that the purpose of separating powers between two governments as well as within the federal government was to create a system "where the constant aim is to divide and arrange the several offices in such a manner as that each may be a check on the other-that the private interest of every individual may be the sentinel over the public rights." Because each branch has only limited ways by which to counteract the ambitions of the other branches, the only way the Court can apply its check is by invalidating acts of government that exceed the actor's constitutionally defined scope of power.

The argument continues that the Framers would not have understood a Court exercising this supervisory power to undermine democracy or interfere with legitimate policy making. ${ }^{112}$ For Hamilton, judicial review in general did not enable the Court to "attack" the other branches with success; rather judicial review was the Court's power "through the medium of ... justice" to preserve "limitations" on legislative and executive authority. ${ }^{113}$ The Court would not "substitute [its] own pleasure to the

can do no wrong"). Similarly, in Marbury, the Court held that laws enacted by Congress that were repugnant to the Constitution were necessarily void. See Marbury, 5 U.S. at 176. Had it not, the legislative branch would have retained much of the power that state legislatures had in the postRevolutionary, pre-Framing time period: By legislative fiat, it could have expanded or contracted the powers and duties of the executive and the judiciary.

108. THE FEDERALIST No. 51, supra note 103, at 322 (James Madison); see also THE FEDERALIST No. 72, supra note 103, at 435 (Alexander Hamilton).

109. The Federalist No. 51, supra note 103, at 320 (James Madison) (emphasis added).

110. See THE FEDERAL1ST No. 10, supra note 103, at 77-84 (James Madison) (articulating his theory of faction); see also THE FEDERALIST No. 6, supra note 103, at 54 (Alexander Hamilton) (noting that "men are ambitious, vindictive, and rapacious").

111. THE FEDERAL1ST No. 51, supra note 103, at 322 (James Madison).

112. Rebecca Brown makes a similar first-principle argument to defend the whole notion of judicial review as properly serving a tyranny-minimizing function, rather than interfering with majoritarianism, which she claims is a modern (mis)understanding of our representative democracy. See Brown, supra note 100 , passim.

113. The Federalist No. 78. supra note 103, at 466 (Alexander Hamilton). The division of power between the national government and the states, and the divisions of power within those loci of power, provides an important safeguard against aggrandizement of power within a particular institution of government. Madison described this "double security" as follows:

In the compound republic of America, the power surrendered by the people is first divided between two distinct governments, and then the portion allotted to each subdivided among distinct and separate departments. Hence a double security arises to the rights of people. The 
constitutional intentions of the legislature;" rather it would exercise its judgment to declare acts contrary to the Constitution void. ${ }^{14}$ Thus, the Court's duty would be to secure "[t]he inflexible and uniform adherence to the rights of the Constitution, and of individuals ...."115 These rights arguably include both the liberties enumerated in the Bill of Rights and the liberties reserved in ceding power only to a divided, limited government. ${ }^{116}$

Several commentators have suggested that the Court should play a far less active role in structural disputes. ${ }^{117}$ Many of these commentators believe that the Court should save its exhaustible institutional capital by avoiding resolving disputes between branches or levels of government, except when the Court's limited power is threatened. They argue that the Court best serves its checking function, and is most able to do so, when protecting individuals who have limited or no access to the political process, as opposed to the politically powerful states and several branches of government. ${ }^{118}$ Others argue that judicial review is undemocratic and antimajoritarian generally; thus, they seek to limit its application to the smallest number of instances. ${ }^{119}$ Still more contend that the Court has not only gotten separation-of-powers questions wrong consistently, but also that it has repeatedly invalidated mechanisms that the branches developed to restore the balance of power in light of the growing power of the executive and the administrative state. ${ }^{120}$ Given such a poor track record and the difficulty in deciding when and how to address separation-of-powers questions,

different governments will control each other, at the same time that each will be controlled by itself.

The Federalist No. 51, supra note 103, at 323. Justice Brennan employed this double-security theory quite convincingly in his efforts to safeguard individual liberties. See Robert C. Post, Justice Brenman and Federalism, 7 Const. Commentary 227 passim (1990).

114. The Federalist No. 78, supra note 103, at 468-69 (Alexander Hamilton).

115. Id. at $470-471$.

116. See Morrison v. Olson, 487 U.S. 654, 697 (Scalia, J., dissenting).

117. See Jesse H. Choper, Judicial Review and the National Political Process 1-3, 263 (1980); see also Jesse H. Choper, The Scope of National Power Vis-â-Vis the States: The Dispensability of Judicial Review, 86 YALE L.J. 1552 (1977); Herbert Wechsler, The Political Safeguards of Federalism: The Role of the States in the Coniposition and Selection of the National Government, 54 Colum. L. Rev. 543 (1954).

118. See CHOPER, supra note 117, at 2-3; see also id. at 263 (arguing that separation-of-powers disputes should be held nonjusticiable). But see Yoo, supra note 99, at 1312-14 (arguing that the Court's recent federalism decisions evince the Court's abandonment of Wechsler's and Choper's political safeguards theory).

119. Rebecca Brown canvasses the literature that makes these pervasive arguments, see Brown, supra note 100, at 531-546, but for reasons stated earlier, see supra note 112 , she rejects them as misguided and historically inaccurate. See id. at 577-78. 1n countenancing piecemeal expansion of power in one branch, the Court arguahly risks that one day it will not be able to check effectively an overly powerful unit of government, such as existed before the Framing. While affirmatively protecting individual rights is of great importance for the Court, so too is protecting the form of government that the Framers decided would best insure the security of those rights.

120. See. e.g., Martin S. Flaherty, The Most Dangerous Branch, 105 YALE L.J. 1725, 1832 (1996). 
such scholars suggest that the Court's intervention in this area should be "coufined either to violations of clear textual provisions relating to the apex of the three branches or to clear breaches of underlying separation of powers principles themselves."12!

Regardless with which camp one chooses to side, it is difficult to deny that the Court and its individual members have started paying more attention of late to disputes regarding the structure of government. ${ }^{122}$ Within this growing line of cases, the Court's separation-of-powers jurisprudence, unlike its federalism jurisprudence, ${ }^{123}$ has been inconsistent. It has vacillated between a formalist approach, which seems faithful to Madison's vision of "separate and distinct powers of government," functionalist approach, which takes notice of the changing face of modern government. ${ }^{125}$ The latter mode of inquiry involves a far more deferential notion of judicial review.

121. Id. at 1828 .

122. Professor Choper has suggested that the Rehnquist Court has shifted its focus from the Warren-Burger Court battle over defiuing individual rights to battles over defining the constitutional structure of government, and in particular, the boundaries of federalism. See Jesse H. Choper, On the Difference in Importance Between Supreme Court Doctrine and Actual Consequences: A Review of the Supreme Court's 1996-1997 Term, 19 CARDOzo L. REv. 2259, 2309 (1998). Evidence of this shift can be found in what have been characterized as several of the "big" cases of the last few terms. See, e.g., Alden v. Maine, 119 S. Ct. 2240 (1999) (holding Congress could not subject state to suit in state court withont state's consent); Printz v. United States, 117 S. Ct. 2365 (1997) (holding Congress could not commandeer state officers by forcing sheriffs to perform backgronnd checks on would-be gun purchasers); City of Boerne v. Flores, 117 S. Ct. 2157 (1997) (striking down the Religious Freedom Restoration Act on separation-of-powers and federalism grounds); Seminole Tribe v. Florida, $116 \mathrm{~S}$. Ct. 1114, 1119 (1996) (holding that "notwithstanding Congress' clear intent to abrogate the States' sovercign immunity, the Indian Commerce Clause does not grant Congress that power"); United States v. Lopez, 514 U.S. 549, 564 (1995) (holding unconstitutional, for first time in sixty years, an act of Congress pursuant to its Article I, section 8 commerce clause power on the grounds that the Gun-Free School Zone Act interfered with areas in which "States historically have been sovereign"); New York v. United States, 505 U.S. 144 (1992) (holding Congress could not "commandeer" state legislatures and force states to either adopt environmental cleanup measures or take title to waste sites); Lujan v. Defenders of Wildlife, 504 U.S. 555 (1992) (holding that in order to vindicate the public interest Congress conld not confer standing to citizens in cases im which Article II1 standing requirements are not met because (1) the Court did not have the power to hear such cases; and (2) allowing citizens to vindicate the public interest in courts infringed executive's constitutional duty to take care that laws be faithfully executed).

123. See cases collected supra note 122. The Court's federalism cases mentioned above have consistently readjnsted the balance of power between the federal government and the states in favor of the states.

124. The Federalist No. 51. supra note 103, at 321 (James Madison).

125. See supra notes 24 and 91; see also Rebecca L. Brown, Separated Powers and Ordered Liberty, 139 U. PA. L. Rev. 1513, 1522-31 (1991) (discussing formalism/functionalism distinction); Peter L. Strauss, Formal and Functional Approaches to Separation-of-Powers Questions-A Foolish Inconsistency?, 72 CORNELL L. REv. 488 (1987) (coining the terms). The early development of this distinction can be traced back to a comparison of Justice Black's formalist opinion and Chief Justice Vinson's functionalist dissent in Youngstown Sheet \& Tube Co. v. Sawyer, 343 U.S. 579, 587 (1952) (Black, J.) ("In the framework of our Constitution, the President's power to see that the laws are faithfully execnted refutes the idea that he is to be a lawmaker."); id. at 702 (Vinson, C.J., dissenting) 
Justice White, for example, believed that "formalistic and unbending rules' in the area of separation of powers may 'unduly constrict Congress's ability to take needed and innovative action."126 The formalist approach, which, on the current Court, Justice Scalia most faithfully employs, unbendingly adheres to an original understanding of the Constitution and the historical record. As Scalia writes, the Framers "viewed the principle of separation of powers as the absolutely central guarantee of a just Government."127 They recognized " [t] he insufficiency of a mere parchment delineation of the boundaries." 128 Justice Scalia therefore insists that the Court vigilantly guard against the concentration of power in one branch. He disagrees with the functionalist approach, because "[i]n the long run the improvisation of a constitutional structure on the basis of currently perceived utility will be disastrous." 129

The theoretical debate among the Justices proves as contentious and unresolved as is the debate among scholars. These theoretical divides alone do not, however, satisfactorily explain the Court's separation-of-powers jurisprudence. Justices Scalia and White have most often written for themselves in their separation-of-powers decisions, and scholarly impact on the Court's jurisprudence has not yet straightened the Court's course. The next Section attempts to sketch the often zagging line that is the Court's separation-of-powers jurisprudence.

\section{Reviewing the Supreme Court's Practice in Separation-of-Powers} Cases: An Attempt to Identify Indicia of a Separation-of-Powers Violation

An early Supreme Court nondecision exemplifies the essential elements the Court relies upon in its separation-of-powers cases. When the values underlying these elements are in fact or potentially threatened, the Court is left with good indications that a separation-of-powers violation is present. And in these cases, the Court usually finds one.

("Flexibility as to mode of execution [of the laws] to meet critical situations is a matter of practical necessity.").

126. Bowsher v. Synar, 478 U.S. 714, 763 (1986) (White, J., dissenting) (quoting Commodity Futures Trading Comm'n v. Schor, 478 U.S. 833, 851 (1986)); see also Bowsher, 478 U.S. at 774, 776 (White, J., dissenting) ("Realistic consideration ... reveals that the threat to separation of powers conjured up by the majority is wholly chimerical;" "The majority's [reliance] on rigid dogma and unyielding principle to strike down a statute posing no real danger of aggrandizement of congressional power is extremely misguided and insensitive to our constitutional role."); INS v. Chadha, 462 U.S. 919, 1002-03 (1986) (White, J., dissenting) (arguing that in striking down the legislative veto in the context of the administrative state that the Court has sanctioned, the Court has made it more difficult to insure that fundamental policy decisions would be made by elected officials rather than appointcd administrative officials).

127. Morrison v. Olson, 487 U.S. 654, 697 (1988) (Scalia, J., dissenting).

128. Id. at 698 (quoting The Federalist No. 73, at 442 (Alexander Hamilton) (Clinton Rossiter ed., 1961)).

129. Mistretta v. United States, 488 U.S. 361, 427 (1989) (Scalia, J., dissenting). 
In 1793, the Supreme Court refused the executive branch's request to advise President Washington in interpreting treaties between the United States and France. ${ }^{130}$ The Jay Court's decision not to honor the request is the best early example of the separation of powers at work in our constitutional government. In analyzing this nondecision, one can identify several separation-of-power values. Examination of the Supreme Court's subsequent jurisprudence reveals that when one or several of these values is ignored, it is likely that a separation-of-powers violation can be found. The next three Sections discuss these values and indicia of violations.

\section{An Aggrandizement of Power}

The first value the Jay Court recognized in Correspondence of the Justices was that of protecting against the aggrandizement of power in a branch of government not constitutionally entitled to it. In its letter to President Washington, the Jay Court refused to offer the requested advice because to do so would exceed the bounds of the Court's power as defined in Article III. (In more modern parlance, the President's letter did not present a "Case or Controversy.") The Court's explicit refusal to act "extrajudicially," that is, beyond its powers enumerated in Article III, set an important precedent. ${ }^{131}$

Over time, the Court has insisted that the Constitution and not the branches themselves define the limits of the several branches' power. In doing so, the Court protects against one of the greatest dangers to libertyunchecked power. ${ }^{132}$ In the last century, the Court has accordingly used the anti-aggrandizement principle to reach several important holdings, for example: (1) to invalidate presidential action that has exceeded the office's constitutionally defined power; ${ }^{133}$ (2) to invalidate acts of

130. See Correspondence of the Justices, reprinted in 3 CORRESPONDENCE AND Public PAPERS OF JoHn JAY 486-89 (Johnston ed., 1891). The Justices' letter to the President is short, but sweet, in constitutional insight:

Sir:

We have considered the previous question stated in your letter written to us by your direction by the Secretary of State on the 18th of last month. The lines of separation drawn by the Constitution between the three departments of government-their being in certain respects checks upon each other-and our being judges of a court in the last resort-are considerations which afford strong arguments against the propriety of our extrajudicially deciding the questions alluded to; especially as the power given by the Constitution to the President of calling on the heads of departments for opinions, seems to have been purposely as well as expressly limited to the executive departments.

Id. (emphasis in original).

131. Id.

132. See supra Part 11.B-C.

133. See, e.g., Youngstown Sheet \& Tube Co. v. Sawyer, 343 U.S. 579 (1952) (holding that the President did not have power to seize nation's steel mills). 
Congress that enlarge Congress's power vis-à-vis the other branches; ; $^{134}$ and (3) to help invigorate the Court's standing jurisprudence. ${ }^{135}$ Regardless of the way in which the Court employs the principle, it always does so with the goal of preserving the separation of powers. ${ }^{136}$

In these opinions, the Court guards against aggrandizement, focusing on the text of the Constitution, the history surrounding the text, and the nature of the power at issue. First, the Court determines whether a specific provision in the text of the Constitution authorizes or forbids the specific exercise of power being challenged. In INS v. Chadha ${ }^{137}$ for example, the Court held that the Bicameralism and Presentment Clauses ${ }^{138}$ forbid one House of Congress from exercising a legislative veto over an executive branch decision. The legislative veto in Chadha in effect put a resolution passed by one House of Congress on par with a bill upon which both houses and the President agreed. Thus, in creating the legislative veto for itself, Congress improperly aggrandized its power, as defined in Article I's Presentment Clause. In his concurrence in Clinton, Justice Kennedy made a similar charge of aggrandizement but argued that the Line Item Veto Act enhanced the President's power as opposed to increasing that of Congress. ${ }^{139}$ This textual approach proves difficult because the Constitution neither specifically allows nor forbids legislative or line-item vetoes. History thus proves useful in determining the meaning of the text. ${ }^{140}$

When the text and its surrounding history still provide no easy answers, the Court often turns to the type of power being exercised and tries to determine its essential nature. In the Steel Seizure Case, for example, the Court held that Article II did not expressly or implicitly provide President Truman with the power to take possession of and operate the Nation's steel mills during a wartime emergency. ${ }^{141}$ Looking to the nature of the power being exercised, however, the court reasoned that Congress

134. See A. Michael Froomkin, The Imperial Presidency's New Vestments, 88 Nw. U. L. REv. 1346, 1368 (1994) ("[1]n Myers, Buckley, Chadha, Bowsher, and Metropolitan Airport, separation of powers was violated by Congress seeking to reserve an executive power for itself.").

135. See, e.g., Raines v. Byrd, 117 S. Ct. 2312, 2318 (1997) (refusing to find standing where plaintiffs lacked Article III injury, "in ... light of [the] overriding and time-honored concern about keeping the Judiciary's power in its proper constitutional sphere").

136. See Buckley v. Valeo, 424 U.S. 1, 122 (1976) (per curiam) (noting that the separation of powers provide a "safeguard against the ... aggrandizement of one branch at the expense of the other.").

137. 462 U.S. 919 (1983); see also Process Gas Consumers Group v. Consumer Energy Council of Am., 463 U.S. 1216 (1983) (affirming without oral argument, opinion, or citation, presumably on Presentment Clause grounds, a per curiam court of appeals decision invalidating the two-house veto of regulatory rule making).

138. U.S. CoNST. art. I, § 7.

139. See Clinton v. City of New York, 118 S. Ct. 2091, 2110 (1998) (Kennedy, J., concurring).

140. See Chadha, 462 U.S. at $946-52$ (examining the history surrounding the Presentment and Bicameralism Clauses to determine their meaning).

141. See Youngstown Sheet \& Tube Co. v. Sawyer, 343 U.S. 579, 585-89 (1952). 
really possessed such law-making power. Since Congress refused to exercise its constitutional grant of power to make law, or to delegate it to the President, the President was not rightly executing a seizure law that Congress duly enacted. ${ }^{142}$ Similarly, in Metropolitan Washington Airports Authority $v$. Citizens for the Abatement of Airport Noise, Inc. ${ }^{143}$ and Buckley v. Valeo ${ }^{14}$ the Court held that Congress impermissibly aggrandized its powers by placing its members on boards and commissions that exercised executive powers. Again, similarly, in Bowsher v. Synar, ${ }^{145}$ the Court held that Congress had aggrandized its power by retaining sole removal power over a government officer performing executive duties.

\section{An Encroachment upon a Coordinate Branch's Power}

The 1793 Correspondence of the Justices non-case illustrated a second fundamental value of separation-of-powers jurisprudence: the antiencroachment principle, which provides that one branch ought not encroach on the power of the coordinate branches. The Jay Court justified its refusal to issue an advisory opinion because the Constitution "purposely as well as expressly" envisions the President calling upon heads of executive departments to render opinions, and inter alia, interpret treaties. ${ }^{146}$ Thus, if the Court had acquiesced to the executive branch's request, two encroachments would have been present: (1) the Court would have intruded upon the duties specifically assigned to executive branch officers; and (2) the Court would have ceded its finite institutional resources to the

142. See id. Justice Jackson, concurring, expounded the most nuanced opinion in the case. See, e.g., William B. Lockhart et AL., Constitutional Law 179 (8th ed. 1996). Jackson described the fluctuating nature of the President's power as dependent on whether Congress (1) expressly or impliedly approved of the President's action; (2) remained silent on the matter or acquiesced to the President; or (3) expressly or impliedly disapproved of the measures taken by the President. See Youngstown, 343 U.S. at 635-38 (Jackson, J., concurring). In the first instance, the President's power is at "its maximum," id. at 635; in the second, in the "zone of twilight" where "imperatives of events" may justify his use of power, id. at 637; and in the third, at its "lowest ebb," id. Justice Jackson grouped President Truman's actions in the third category and therefore found them unjustified even under war conditions. See id. at 641,653 . It should be noted that formalists, believing in the fixed natures of power in our government, have criticized Jackson for suggesting that Congress could enhance the President's powers or nullify them. See, e.g., Martin H. Redish \& Elizabeth J. Cisar, "If Angels Were to Govern": The Need For Pragmatic Formalism in Separation of Powers Theory, 41 DukE L.J. 449, 484-87 (1991).

143. 501 U.S. 252 (1991).

144. 424 U.S. 1 (1976) (per curiam).

145. 478 U.S. 714 (1986).

146. Correspondence, supra note 130 , at $486-89$ (emphasis in original). 
executive. ${ }^{147}$ As commentators have suggested, the Jay Court likely acted in the way it did because it feared becoming beholden to the President. ${ }^{148}$

The notion that separate branches of government should not encroach upon the duties assigned other branches has proved pivotal in subsequent separation-of-powers cases. In Myers $v$. United States, ${ }^{149}$ the Taft Court held that pursuant to the Appointments Clause, Congress could not limit the President's authority to remove principal executive officers. ${ }^{150}$ In placing restrictions on the President's ability to remove a postmaster, Congress had violated the separation of powers by encroaching upon the President's ability to fulfill his constitutional duty as executive. ${ }^{151}$ More recently, in City of Boerne v. Flores, ${ }^{152}$ the Rehnquist Court invalidated the Religious Freedom Restoration Act of 1993 (RFRA), in which Congress purported to "overrule"153 the Court's decision in Employment Division v. Smith. ${ }^{154}$ City of Boerne held that in passing RFRA, Congress violated the separation of powers by encroaching on the Court's "primary power to interpret and elaborate on the meaning" of the Constitution. ${ }^{155}$ In Clinton, Justice Kennedy voiced similar objections to the Line Item Veto Act, even though

147. The previous year, the Court also had implicitly recognized that rendering advisory opinions undermined the Court's relative power if such opinions could be ignored by the other branches of govemment. See Hayburn's Case, 2 U.S. (2 Dall.) 408 (1792) (holding that Article III courts could not render judgments subject to executive or legislative revision).

I48. See, e.g., LOCKHART ET AL., supra note 142, at 1509 (suggesting that refusal to issue the advisory opinion helped "to symbolize ... the Article Ill judiciary as an independent and co-equal branch of govemment. ... [T] he position taken in the Correspondence of the Justices was "part of a broader attempt by the Supreme Court to deemphasize the obligatory extrajudicial service concept, so widely held in the earlier period'") (quoting Russell Wheeler, Extrajudicial Activities of the Early' Supreme Court, 1973 SuP. CT. Rev. 123, 158).

149272 U.S. 52 (1926).

150. Cf. Bowsher v. Synar, 478 U.S. 714, 726 (1986) ("Congress cannot reserve for itself the power of removal of an officer charged with the execution of laws except by impeachment.").

151. See Myers, 272 U.S. at 132 ("Made responsible under the Constitution for the effective enforcement of the law, the President needs as an indispensable aid to meet it the disciplinary influence upon those who act under him of a reserve power of removal."). Congress arguably aggrandized its powers as well in asserting the authority to place limits on the President's discretion.

152. 117 S. Ct. 2157 (1997).

153. See Flores v. City of Boeme, 73 F.3d 1352, 1355-56 (5th Cir. 1996) (recounting legislative history).

154. 494 U.S. 872,879 (1990).

155. City of Boerne, 117 S. Ct. at 2166 (citing Marbury v. Madison, 5 U.S. (1 Cranch) 137 (1803)). In Morrison v. Olson, however, the encroachment principle was all but ignored. 487 U.S. 654 , 685-96 (1988). There the Court held that Congress did not encroach upon the powers of the executive by creating an Independent Counsel Office, although, as Justice Scalia recognized in his dissent: (1) in bringing prosecutions, the Independent Counsel surely executed the law; (2) the President had extremely limited removal power over the Independent Counsel, and thus, little control over an official supposedly stationed in his branch of government; and (3) investigations conducted by the lndependent Counsel could greatly interfere with the President's and his officers' ability to enforce the law. See id. at 712-13, 723-31 (Scalia, J., dissenting). 
in this case, Congress had invited encroachment on its own power, not on that of a coordinate branch. ${ }^{156}$

\section{Diminishing the State's Accountability to Its Citizens}

The final separation-of-powers value-keeping government accountable to the citizenry-stems not so much from textually defined limits of power or the relationship among the branches as from principles of democracy. ${ }^{157}$ The nondecision in Correspondence of the Justices helped guard against vesting excessive power in a nonelected federal judiciary. ${ }^{158}$ Asking the life-tenured judiciary to decide important matters, such as whether the young country should join France in its war against England, would have shielded the popularly elected Congress and President from the electoral consequences of such a monumental decision. In addition, it would have prevented the public from effectively expressing its opinions to accountable, elected officials about America's involvement in the war. ${ }^{159}$ The Court's other justiciability doctrines-standing, ripeness, mootness, and political question-can be understood as serving the same end. ${ }^{160}$ They prevent the judiciary from resolving issues of public importance that the executive and legislative branches can handle most democratically and most effectively as a matter of policy. Just as the separation of powers doctrine limits encroachment on coordinate branches, so too does it limit government encroachment on the public.

156. See Clinton v. City of New York, 118 S. Ct. 2091, 2109 (1998) (Kennedy, J., concurring).

157. In Clinton, Justice Kennedy described the relationship between branches of government as the separation of powers "operat[ing] on a horizontal axis;" the relationship between "each branch and the citizens," he calls the "[s]eparation of powers operat[ing] on a vertical axis as well." Jd. at 2110. Each branch is thus denocratically accountable to the citizenry in two ways: checked by its co-equal branches, which are themselves accountable to the citizenry, and checked directly by the citizenry itself.

In her recent article, Rebecca Brown forcefully argues that "accountability," or citizen participation as a check on government, furthers American notions of democracy. See Brown, supra note 100 , at $565,571-72$. Brown further argues that in contrast to those believing strongly in the counter-majoritarian difficulty, judicial review supports accountability and democrative governance. See id. at 571 ("[T] he judiciary does not present a 'difficulty,' but is by far the easiest branch to reconcile with a govemment devoted to the preservation of liberty."); see also supra notes 100,112 , and 119. Like political accountability to the citizenry on voting day, such independent review promotes liberty while preventing tyranny. See Brown, supra note 100, at 570-72.

158. See Comment, The Advisory Opinion and the United States Supreme Court, 5 Fordham L. REv. 94, 108 (1936) (stating that the advisory opinion "would debilitate the creative responsibility of the legislature in that it would tend to induce reliance upon the judiciary" (citing Felix Frankfurter, $A$ Note on Advisory Opinions, 37 HaRv. L. REv. 1002, 1005 (1924))).

159. See SHANE \& BRUF, supranote 34 , at 586-93 (reproducing debate and describing political circumstances surrounding the Correspondence of the Justices).

160. Cf. Steel Co. v. Citizens for a Better Environment, 118 S. Ct. 1003, 1016 (1998) ("The statutory and (especially) constitutional elements of jurisdiction are an essential ingredient of separation and equilibrium of powers, restraining the courts from acting at certain times, and even restraining them from acting permanently regarding certain subjects."). 
The Court's nondelegation doctrine-a subset of its separation-ofpowers jurisprudence-ought to serve the same accountability function, but has been under-employed as of late. ${ }^{161}$ In principle, this doctrine holds that Congress, as the branch most representative of the people's will and thus deserving of law-making power, may not delegate its core legislative powers to other branches of government. ${ }^{162}$ Yet in Mistretta $v$. United States, ${ }^{163}$ the Court did not invoke the doctrine where a rigorous separationof-powers theory would have demanded its application. In dissent, Justice Scalia argued that the Sentencing Reform Act of 1984 unconstitutionally vested law-making and executive powers in Article III judges who had no constitutional authority to make or execute laws. ${ }^{164} \mathrm{He}$ asserted that the Court's decision to allow judges to sit on the Federal Sentencing Guidelines Commission, on which they would conduct investigations and prescribe rules, ${ }^{165}$ invited Congress to create a new class of "junior-varsity Congress." Congress could employ these " "expert' bodies" to "dispose of such thorny, 'no win' political issues as the withholding of life-support systems in federally funded hospitals, or the use of fetal tissue for research." 167 Such an abdication of power and responsibility was surely "undemocratic" because it "insulated [Congress and the agencies it created] from the political process" and public accountability. ${ }^{168}$

Given Mistretta, some commentators suggest that the nondelegation doctrine-not used to strike down an Act of Congress since 1935-is effectively dead. ${ }^{169}$ Despite such reports, the majority in Mistretta

161. One commentator notes, "[J]udicial leniency along with the habitual willingness of Congress to delegate to the executive branch vast discretionary power helps to explain the rise since the Great Depression of what Arthur Schlesinger, Jr., calls the 'imperial presidency."' Wallace Mendelson, Separation of Powers, in The Oxford Companion to the Supreme Court of The UNITEd STATES 779 (Kermit L. Hall ed., 1992).

162. See, e.g., A.L.A. Schechter Poultry Corp. v. United States, 295 U.S. 495 (1935) (holding the National Industrial Act unconstitutionally delegated legislative powers to an executive official).

163. 488 U.S. 361 (1988).

164. See id. at 418-27 (Scalia, J., dissenting).

165. See id. at 420-21.

166. Id. at 427 .

167. Id. at 422 .

168. Id. Morrison v. Olson, 487 U.S. 654 (1988), decided the Term before, did similar harm. In Morrison, the problem was dividing power among the executive branch in such a way that the President could not be held accountable for officers acting within his branch of government. See id. at 729 (Scalia, J., dissenting) ("[O]ne of the weightiest objections to a plurality in the executive ... is that it tends to conceal faults and destroy responsibility."' (quoting THE FEDERALIST 70, supra note 103, at 729) (Alexander Hamilton))). The Ethics in Government Act vested unrestrained prosecutorial powers and an almost limitless budget in an officer completely unaccountable to the public and only superficially checked by the other political and nonpolitical branches of government. See id. at 729-31. Fortunately, Congress has decided not to reauthorize the Act. See Robert Suro, As Special Counsel Law Expires, Power Will Shift to Reno, WASH. Post, June 30, 1999, at A6.

169. See Lockhart et al., supra note 142, at 182 (citing 1 KenNeth Culp Davis \& Richard J. Pierce, Jr., Administrative Law Treatise 66-85 (1994)). But compare United States v. Lopez, 514 
recognized the limitation that the nondelegation doctrine sets, whatever that limit might be. ${ }^{170}$ Moreover, the majority's decision in Clinton v. City of New York mentioned the nondelegation doctrine but found it inapposite to its Presentment Clause analysis. The Court's nod to the doctrine suggests that it remains viable. ${ }^{171}$

In fact, INS v. Chadha ${ }^{172}$ has been explained as an example of the Court putting a different type of check on Congress's careless delegation of its power to less publicly accountable executive agencies. One scholar suggests that before Chadha, Congress had recognized "its own carelessness with respect to delegation;" thus, it repeatedly provided for an "after-the-fact remedy called the legislative veto." 173 He continues, "The Chadha ruling ended that approach, which may have been less important as a remedy than as a recognition by Congress that it had been giving away too much authority and had not been performing adequately." 174 Bicameralism and Presentment Clauses as limitations on after-the-fact legislative action-even though the Clauses arguably did not forbid the legislative veto power ${ }^{175}$ - the Court reached a result promoting accountability in the long run that nondelegation would not provide. No matter the means, the Court consciously and explicitly vindicated the separation-ofpowers values at stake. ${ }^{176}$ The Court was careful, however, to justify its interpretation of the two Clauses based on the original understanding of the Clauses and the first principles of the separation of powers that compelled the Framers to include them in our constitutional framework. ${ }^{177}$

****

The next Part argues that much of the same sleight of hand may have been present in Clinton. Based on its holding, one can infer that the Clinton

U.S. 549 (1995) (striking down an act of Congress on Commerce Clause grounds for first time since 1936).

170. See 488 U.S. 361,372 (1985) ("Congress generally cannot delegate its legislative power to another Branch. ... We also have recognized, however, that the separation-of-powers principle, and the nondelegation doctrine in particular, do not prevent Congress from obtaining the assistance of its coordinate Branches.").

171. See Clinton v. City of New York, 118 S. Ct. 2091, 2107-08 (1998). In contrast, Justice Breyer casts doubt on the viability of the doctrine by pointing out the excesses of the two pieces of legislation that the Court struck down on nondelegation grounds. He characterized those two statutes as creating a "roving commission," delegating power "to private parties," and bringing "all of American industry within its scope." Id. at 2126 (Breyer, J., dissenting). If these excesses are the minimum for a nondelegation doctrine violation, perhaps it will remain out of explicit use for another sixty years.

172. 462 U.S. 919 (1983).

173. Mendelson, supra note 161 , at 779.

174. Id.

175. Justice White, dissenting in Chadha, made strong arguments that the one-house legislative veto violated neither the Bicameralisin nor the Presentment Clauses. See Chadha, 462 U.S. at 979-98 (White, J., dissenting); see also infra note 188 (discussing these arguments).

176. See Chadha, 462 U.S. at $945-46,951-59$.

177. See id. 
Court thought that Congress's delegation of power was an abdication of responsibility and an invitation for the executive to act in a manner unaccountable to the citizenry. Instead of saying this in Clinton, however, the Court relied upon a questionable Presentment Clause violation to strike down this congressional delegation of authority to the President. The Court's opinion in Clinton, unlike its decision in Chadha, unfortunately did not identify the separation-of-powers issues at stake in the challenged legislation. Mindful of both the centrality of the separation of powers in our constitutional framework and the indicia of a separation-of-power violation discussed above, the next Part turns to a critique of Clinton.

\section{III}

\section{The Line Item Veto Case Revisited}

The first question the Court should ask in a separation-of-powers case such as Clinton v. City of New York is whether the Constitution expressly authorizes or forbids the exercise of power being challenged. Text and history deserve particular attention. In Clinton, the Court considered whether the cancellation power provided for in the Line Item Veto Act violated the law-making procedures embodied in the Presentment Clause. If the Court answers this first question in the negative, it should ask a second question: whether the exercise of power violates the first principles and values served by the separation of powers. Because the Court answered the first question in the affirmative, it did not reach this question.

In answering the first question, the majority reached two correct, but ultimately irrelevant, conclusions. One cannot quarrel with the majority's conclusion that " $[t]$ here is no provision in the Constitution that authorizes the President to enact, to amend, or to repeal statutes." ${ }^{178}$ In addition, the majority rightly observed that the Constitution does not give the President the power to veto bills in part; it merely gives him the power to "return" to Congress, in whole, "[e]very [b]ill" presented to him of which he "[dis]approves." national security or a budget deficit crisis will not justify the President's exceeding his bounds of power. ${ }^{180}$

These two conclusions provide little guidance in Clinton. The cancellation power at issue in Clinton was not the ability to exercise a piecemeal

178. Clinton v. City of New York, 118 S. Ct. 2091, 2103 (1998) (““‘[R]epeal of statutes, no less than enactment, must conform with Art. I."' (quoting Chadha, 462 U.S. at 954)).

179. U.S. Const. art. 1, $\S 7$, cl. 2; see also Clinton, 118 S. Ct. at 2104 ("Our first President understood the text of the Presentment Clause as requiring that he either approve all parts of a Bill, or reject it in toto." (quoting 33 WRITINGS OF GEORGE WASHINGTON 96 (J. Fitzpatrick ed., 1940))). But some commentators argue that line-item veto power is provided for in the Constitution. See supra note 34.

180. See supra notes 90 (discussing Bowsher) and 141-42 and accompanying text (discussing the Steel Seizure Case). 
veto power or effectively to amend or to repeal statutes. As those dissenting in Clinton correctly concluded, it represented the exercise of a discretionary executive power that Congress delegated to the President. ${ }^{181} \mathrm{He}$ exercised this executive power to cancel after meeting his law-making obligation under the Presentment Clause to return the bill in whole to Congress rather than to veto it in whole. Thus, as Part III.A below argues, the majority was wrong to conclude that the Presentment Clause forbids the line-item veto.

Although the majority did not reach the second question courts must ask in cases such as Clinton, in which the text and history are not clear, answering that question shows that the Line Item Veto Act upsets the separation of powers. ${ }^{182}$ While it may not violate the Court's lax nondelegation doctrine, the Act threatened liberty and evinced the indicia normally associated with a separation-of-powers violation. Part III.B below makes this argument.

Parts III.A and B, which follow, highlight the crux of this Comment: The Court should not have invalidated the Line Item Veto Act on Presentment Clause grounds, but rather, on separation-of-powers grounds. While the Presentment Clause is one instance of the Constitution giving effect to the separation of powers, its application was inappropriate in this case. Only straightforward separation-of-powers analysis, as evinced in Justice Kennedy's concurring opinion, illuminates the principle's underlying values and logically defends the result in this case. Part III.C speculates as to the Court's reasons for not embracing an explicit separation-of-powers analysis in Clinton.

\section{A. The Line Item Veto Act and the Presentment Clause}

\section{The Origins of the Presentment Clause}

The Presentment Clause provides that "[e]very Bill which shall have passed the House of Representatives and the Senate, shall, before it become a law, be presented to the President of the United States; If he approve he shall sign it, but if not he shall return it." 183 In Chadha, Chief Justice Burger mined the historical record for the reasons why the Framers included the Presentment Clause and constructed it the way they did. The Framers uniformly agreed ${ }^{184}$ on its inclusion because of the affirmative power it gave the President to protect the executive branch from Congress

181. See Clinton at 2115-18 (Scalia, J., concurring in part and dissenting in part); id. at 2120-23 (Breyer, J., dissenting).

182. See id. at 2102-03.

183. U.S. CONST. art $1, \$ 7, \mathrm{cl} .2$.

184. See 1NS v. Chadha, 462 U.S. 919,946 (1983) (citing 1 JOSEPH StORY, COMmENTARIES ON the Constitution of the United States 611 (3d ed. 1858); 1 Max Farrand, The Records of the Constitutional Convention of 1787 , at 21, 97-104, 138-140 (1911)). 
and the people from improvident, oppressive, or ill-considered laws. ${ }^{185}$ The President's unilateral veto power was of course not absolute; it was checked by Congress's ability to override the President's veto with a twothirds majority vote. ${ }^{186}$ Still, the Presentment Clause's essential purpose was to check congressional powers based "on the profound conviction of the Framers that the powers conferred on Congress were the powers to be most carefully circumscribed." 187

The Presentment Clause thus seems best understood as included in the Constitution to limit Congress's power. As such, it exists to protect, not constrain, the President's power vis-à-vis Congress. In Chadha, when Congress removed the President's veto from what the Court characterized as the law-making process, ${ }^{188}$ a Presentment Clause violation obtained. In using the legislative veto to make law "without submission to the President," Congress flouted the Framers' clear intent that the President "check arbitrary governmental acts" and that "legislation by the national Congress be a step-by-step, deliberate and deliberative process," however inefficient that may be. ${ }^{189}$

\section{The Cancellation Power and the Presentment Clause}

Pursuant to the Line Item Veto Act, Congress gave the President the authority to cancel three types of spending provisions included in duly enacted laws. ${ }^{190}$ The majority in Clinton held that this delegation of power, like the legislative veto power that Congress employed in Chadha, upset the delicate law-making process for which the Presentment Clause provides: It gave the President the power to "amend[] two Acts of Congress by repealing portions of each. '[R]epeal of statutes, no less than enactment, must conform with Art. I." "191 The majority was unconvinced by government arguments that the Act delegated executive power to the

185. See Chadha, 462 U.S. at $947-48,951$; see also Wood, supra note 102, at 552-53.

186. See Chadha, 462 U.S. at 951 (citing 1 FARRAND, supra note 184, at 99-104); see also RAKOVE, supra note 39, at $258,263$.

187. See Chadha, 462 U.S. at 947 ; see also RAKove, supra note 39, at 263; Wood, supra note 102. at $552-53$.

188. See Chadha, 462 U.S. at 952 ("Examination of the action taken here by one House ... reveals that it was essentially legislative in purpose and effect."). Justice White disputed this conclusion in his lengthy dissent and advanced two main lines of argument. First, he argued that executive agencies regularly engage in law making, yet no one argues that the laws they promulgate must be subject to bicameral agreement in Congress or to the presidential veto. See id. at 986-87 (White, J., dissenting). Second, he argued that not only did the legislative veto not violate the explicit terms of the Bicameralism and Presentment Clauses, see id. at 980, it did not violate the separation of powers because it did not allow the type of unilateral law making that the Bicameralism and Presentment Clauses guard against, see id. at 994-95.

189. Id. at 958-59.

190. See 2 U.S.C. $\$ 691$ (a) (Supp. II 1997). By "duly enacted laws," 1 mean laws that Congress passed and the President signed into law. The cancellation power becomes triggered only once those two steps-envisioned in the Presentment Clause-have occurred.

I91. Clinton v. City of New York, 118 S. Ct. 2091.2103 (quoting Chadha, 462 U.S. at 954). 
President. ${ }^{192}$ Thus interpreted, the majority held that the Act impermissibly expanded the President's limited role in the law-making process.

The majority's reasoning suffers from two defects. First, in canceling spending provisions, the President does not veto line items as the Act's deceptive title implies. Instead, in making such cancellations the President exercises discretionary authority delegated to him by the Line Item Veto Act and later-enacted statutes that are subject to it, in order to cancel spending provisions contained in these later-enacted statutes. Therefore, unlike in Chadha, the law-making process, which is governed by the Presentment Clause, was not even implicated in Clinton. Second, in invoking the Presentment Clause and its interpretation in Chadha, the majority seemed to use the Clause for an end for which it was not intended: checking the President's power rather than protecting it. These two defects are discussed in turn.

\section{a. The Cancellation Power as an Exercise of Delegated Authority}

i. The Workings of the Line Item Veto Act

For the President to exercise his cancellation power provided for in the Line Item Veto Act and to cancel a statutory provision, two conditions must exist. First, the statute and its provisions must be subject to the Act. ${ }^{193}$ In Clinton, the Taxpayer Relief Act and the "item of new direct spending" in the Balanced Budget Act were explicitly subject to the line-item veto. ${ }^{194}$ Thus, under the Act, the President could have exercised his cancellation power only when Congress said he could; it was not like the unilateral veto power provided for in the Presentment Clause, of which Congress cannot strip the President. Second, the Act required the President to make and report certain findings before canceling an item. ${ }^{195}$ These findings include determining whether the provision increases the federal budget deficit, whether it is essential to government functions, and whether it is necessary to avoid harm to the national interest. ${ }^{196}$

President Clinton made these findings in Clinton. ${ }^{197}$ Invoking the cancellation power subsequent to making such findings is consistent with the execution, rather the amendment or repeal (making) of law, because the President canceled items within a given Act only after he signed the Act into law. The power to cancel and direct the saved moneys to deficit

192. See id. at 2105-07.

193. See 2 U.S.C. § 691(a) (Supp. 11 1997).

194. Clinton, $118 \mathrm{~S}$. Ct. at 2093.

I95. See 2 U.S.C. $\$ 691(\mathrm{a})(3)(\mathrm{B})$.

196. See id. $\$ \S 69 I(a)(3)(A), 691(b)$.

I97. See Clinton, 1 I8 S. Ct. at 2095-96. 
reduction $^{198}$ arose once the Act became law, and, as would an executive agency, the President had to make certain findings before exercising that power. If the President's subsequent decision to spend money to reduce the deficit or to effectuate a line item-contingent upon the initial grant of power-upset Congress, Congress retained the ability to pass a new law disapproving the cancellation and reversing his executive judgment.

Justice Breyer provided another good example why President Clinton's cancellations did not effect a repeal or amendment of the Taxpayer Relief Act, the Balanced Budget Act, or any of their provisions. In exercising his discretion to choose which provisions in the Acts to execute, President Clinton acted much like the beneficiary of a trust. ${ }^{199}$ Imagine a person $Z$ whose trust instrument grants beneficiary $B$ the guided discretionary power to appoint property to $A$ or to $C$. If $B$ chooses $A$ pursuant to his discretion, he does not amend or undo the provisions created in $Z$ 's private law-making process. ${ }^{2(x)}$ Adhering to the trust's text, $B$ merely executes $Z$ 's private law. The language saying property may be appointed to $C$ still exists, but it is inoperative. In Breyer's words, the trust instrument, "in delegating the power of appointment, has not delegated a power to amend or to repeal the instrument; to the contrary, it requires the delegated power to be exercised in accordance with the instrument's terms."201

Similarly, pursuant to the Line Item Veto Act, the President does not add a step to or undo the Presentment Clause's public law-making process. When he exercised his delegated authority to choose which among many provisions in an appropriations bill he would execute, he did not amend or repeal those provisions that he canceled. In executing his duties under the Act, he merely chose "how to spend the money to which the line item refers-either for the specific purpose mentioned [in] the item, or for general deficit reduction. ..."202 The first choice-to spend the money on the line item-is like choosing person $A$, above. The alternative choice created in the statute is to spend the money on deficit reduction-like choosing person $B$ above. In either instance, the President executes the statute; he does not amend it.

\section{ii. Analogous Grants of Executive Power}

Justices Scalia and Breyer, in addition, catalogued a series of cases, statutes, and historical events that bolstered the conclusion that Congress

198. The President can be sure that line-item cancellations directly help reduce the deficit because the Line Item Veto Act "ensures that savings resulting from cancellations are used to reduce the deficit, rather than to offset deficit increases arising from other laws." See id. at 2104 n.31.

199. See id. at 2121 (Breyer, J., dissenting) (citation omitted).

200. See id.

201. Id.

202. Id. at 2123 . 
can vest such discretionary power in the President without upsetting the Presentment Clause's "finely wrought" law-making process. ${ }^{203}$ In each case they cited, a President or other noncongressional government actor exercised a delegated power which had the effect of rendering a statutory provision without force. In no case until Clinton did the Court find a Presentment Clause violation.

Justice Scalia cited two seminal cases, Field v. Clark ${ }^{204}$ and Bowsher v. Synar, ${ }^{205}$ as examples of instances in which the Court could have found a Presentment Clause violation but chose not to do so. In Field, the Court upheld the Tariff Act of 1890 , which directed the President to remove a country's imports from an import duty-free list whenever the President was satisfied that the country imposed certain duties on American exports. ${ }^{206}$ In doing so, the Court recited "the history since 1798 of statutes conferring upon the President the power to, inter alia, 'discontinue the prohibitions and restraints hereby enacted and declared,'... 'suspend the operation of the aforesaid act,' ... 'and declare the provisions of this act to be inoperative." "207 Similarly, Justice Scalia observed that the statute the Court struck down in Bowsher v. Synar was not held unconstitutional because it allowed the President to sequester, and thus "permanently cancel[],", funding amounts appropriated by statute. ${ }^{208}$ Instead, the Court held it violated the separation of powers because it gave Congress control over the executive official implementing the President's order. ${ }^{209}$

The majority's attempt to distinguish Field $v$. Clark as well as similar cases and statutes failed. The Clinton majority found "three critical differences" between the President's power under the Tariff Act and the Line Item Veto Act. ${ }^{210}$ None of these differences compels the conclusion that the Line Item Veto Act violates the Presentment Clause while the Tariff Act does not.

The first such difference between Field and Clinton involved the amount of time that lapsed between the congressional delegation of power and the President's exercise of that power. Under the Tariff Act the decision to impose import duties depended on future events. By contrast, under the Line Item Veto Act, the President's decision whether or not to cancel

203. Id. at 2104; see id. at 2115-17 (Scalia, J., concurring in part and dissenting in part); id. at 2121-23 (Breyer, J., dissenting).

204. 143 U.S. 649 (1892).

205. 478 U.S. 714 (1986).

206. See Field, 143 U.S. at 500. Field was a foreign affairs case, and thus, its import in a domestic spending case such as Clinton is arguably limited. For a further discussion of the weight of this distinction, see note 222 infra.

207. Clinton, $118 \mathrm{~S}$. Ct. at 2116 (Scalia, J., concurring in part and dissenting in part) (quoting Field, 143 U.S. at $684,685,688$ ).

208. Id. (quoting 2 U.S.C. $\$ 902(a)(4)$ (1982 ed., Supp. III)).

209. See Clinton, $118 \mathrm{~S}$. Ct. at 2116.

210. Id. at 2105 . 
spending items-which must take place within five days after a bill is enacted-depended on present conditions. ${ }^{211}$ According to the majority, in exercising his power under the Line Item Veto Act, the President impermissibly substituted his policy judgment for that of Congress because in making cancellation decisions, he relied on the same set of facts as Congress did.

But as can be extrapolated from Justice Breyer's example above, ${ }^{212}$ the time at which one executes the language of a legal instrument does not alter or nullify its text, it only suggests the degree of discretion the instrument confers. In executing a statute subject to the Line Item Veto Act, the President did not engage in the executive law making that Article I forbids; rather, he executed the law as Article II mandates. ${ }^{213}$ True enough, Congress gave the President broad discretion to make policy judgments regarding the budget deficit. However, the true limitation on the delegation of discretionary powers delegated to the President is found in the nondelegation doctrine and separation-of-powers principles discussed below, and not in the Presentment Clause. If within the confines of that doctrine and those principles, Congress wants to cede discretionary authority to the President, it is its own doing. ${ }^{214}$ It is not the business of the Court or the Presentment Clause to say otherwise.

According to the majority, the second critical flaw in the Line Item Veto Act was that it gave the President too much discretion in exercising his cancellation power. Under the Tariff Act, the President had the duty to make findings of fact about certain international conditions. Should he find those facts, he was automatically required to apply the Act's exemption removal provision. ${ }^{215}$ The Line Item Veto Act, by contrast, required that the President make three findings of fact before canceling a spending item. ${ }^{216}$ It did not compel the President to make a cancellation even if he found those facts. ${ }^{217}$

Although this difference may implicate other constitutional doctrines, such as the nondelegation doctrine or the separation of powers, it does not amount to a Presentment Clause violation. As Justice Breyer argued, that a trust gives the beneficiary boundless discretion to choose which provisions

211. See id.

212. See supra notes 199-202 and accompanying text.

213. Cf. Clinton, 118 S. Ct. at 2123-24 (Breyer, J., dissenting) (listing examples of statutes which grant the executive some rule-making power and still do not violate Presentment Clause).

214. See id. at $\mathbf{2 1 2 2}$ ("The legislature cannot delegate its power to make a law; but it can make a law to delegate a power." (quoting Locke's Appeal, $72 \mathrm{~Pa} .491,498$ (1873))).

215. See id. at 2105 (majority opinion). Justice Breyer disputed this point, arguing that some of the tariff statutes discussed in Field actually imposed no duty on the President, while others imposed the duty in such vague terms that the President was left with substantial discretion. See id. at 2129-30 (Breyer, J., dissenting).

216. See 2 U.S.C. \$ 691(a) (Supp. 11 1997).

217. See id. 
in the trust he should execute does not alter or amend the text of the trust. ${ }^{218}$ It means the drafter may have unwisely given the beneficiary too much discretion. While contract law may not police such lapses in judgment, our Constitution does. But it is in employing the nondelegation doctrine and in adhering to the separation of powers, not reinventing the Presentment Clause, that our Court should circumscribe Congress's ability to vest discretionary policy-making authority in the executive.

The third critical difference the Clinton majority recognized between the Line Item Act and the Tariff Act in Field was equally unpersuasive evidence of a Presentment Clause violation. The majority reasoned that when the President removed items from the import duty free list under the Tariff Act, "he was executing the policy that Congress had embodied in the statute." ${ }^{219}$ The Court continued by stating that when the President canceled a spending provision, he substituted his policy judgment for that of Congress. ${ }^{221}$

Upon closer review, this is not the case. By subjecting a statute to the Line Item Veto Act, Congress codified the following policy judgment: The President may cancel any expenditures which he believes are not vital to national policy objectives and whose cancellation could reduce the budget deficit. In canceling provisions in the Taxpayer Relief Act and the Balanced Budget Act, President Clinton used his discretionary authority to effectuate this policy judgment. ${ }^{221}$ Relying on this exercise of executive judgment is much like relying upon the EPA or OSHA to set basic health and safety standards. Again, if Congress had given the President too much authority, the Court could have invalidated the grant of power as inconsistent with a government of separated powers. ${ }^{222}$ A Presentment Clause violation was nowhere to be found.

Justice Breyer cited yet another valid statute undermining the Clinton majority's Presentment Clause holding. Again, the majority failed to distinguish it convincingly. In 28 U.S.C. $\$ 2702$ (b), Congress authorized the Supreme Court "to promulgate rules of practice and procedure in federal courts." 223 The statute further provides that "All laws in conflict with such

218. See Clinton, $118 \mathrm{~S}$. Ct. at 2121 (Breyer, J., dissenting) (citing William J. Bowe \& Douglas H. Parker, Page on the Law of Wills $\$ 45.8$ (Rev. 3 d ed. 1962)).

219. Clinton, $118 \mathrm{~S}$. Ct. at 2106.

220. See id.

221. See id. at 2130 (Breyer, J., dissenting).

222. The majority also distinguished the tariff and import statutes discussed in Field on the ground that they involved foreign affairs, an arena in which the President has heightened discretion. See id. Again, as Justice Scalia observed, that point goes to "whether the authorizations went too far by transferring to the Executive a degree of political, law-making power that our traditions demand be retained by the Legislative Branch." Id. at 2116 (Scalia, J., concurring in part and dissenting in part). It has "nothing to do with whether the details of [the Presentment Clause] have been complied with." Id.; see also id. at 2130 (Breyer, J., dissenting) (making similar argument).

223. Id. at 2121 (Breyer, J., dissenting). 
rules shall be of no further force and effect.",224 How the Supreme Court can constitutionally employ this delegated "contingent power to deny effect to certain statutory language," while the President cannot without violating the Presentment Clause, is unclear. ${ }^{225}$

The Clinton majority attempted to distinguish $\S 2702$ using versions of the critical-difference arguments it used to distinguish the Tariff Act from the Line Item Veto Act.226 Transported, these argument remain unconvincing. The majority argued that in enacting $\S 2702(\mathrm{~b})$, Congress, not the Court, decided that the Court's new procedural rules would trump earlier legislation. Section 2702, according to this logic, did not violate the Presentment Clause. ${ }^{227}$ Likewise, the Line Item Veto Act should comport with the Presentment Clause. When the President decided to cancel a spending item, he would exercise the same type of delegated authority that the Court did when it decided to promulgate a new rule of procedure. The decisions in both cases have the same legal effect, just as Congress intended. The Court's new procedural rule prevents the supplanted statute from having "future force or effect." 228 The President's decision prevents the spending item "from having legal force or effect." 229 Either both statutes violate the Presentment Clause or neither does. ${ }^{230}$

In suin, the President's power, created by the Line Item Veto Act, to take money devoted to line items in spending bills and to use it to help reduce the budget deficit instead, did not amount to the power to make or repeal the law in violation of the Presentment Clause's law-making procedures. The inajority's attempt to use the Court's Presentment Clause analysis and holding in Chadha to support the opposite conclusion proves unconvincing.

\section{b. Distinguishing the Presentment Clause Violation in Chadha}

The majority in Clinton cited Chadha for the proposition that in tinkering with the "finely wrought" "231 law-making process, Congress violated the Presentment Clause when it enacted the Line Item Veto Act. As seen above, $^{232}$ the Framers crafted the Presentment Clause to give the President a limited veto power, not to limit congressional delegations of power. Although the Clause indeed describes the President's role in the

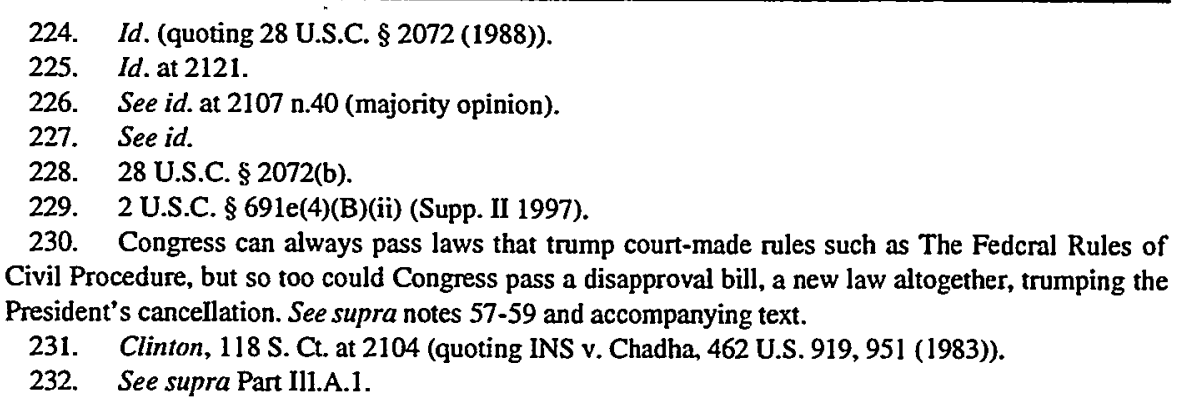


law-making process, the historical record that Chief Justice Burger uncovered in Chadha seems to suggest that the Clause's main purpose was to provide a check on Congress. ${ }^{233}$ Admittedly, if Congress gave the President an absolute veto that no supermajority of Congress could override, such a delegation would give the President a power the Framers did not envision. ${ }^{234}$ Similarly, if Congress gave the President the ability to repeal federal laws at will, a Presentment Clause violation would obtain. However, as Chief Justice Burger's analysis in Chadha shows, the gravamen of a Presentment Clause violation lies in removing the President from the law-making process, not enhancing his role in it. ${ }^{235}$

The exchange between Justice White's dissent and the Chief Justice's majority opinion in Chadha illustrates this point. In Chadha, Justice White objected to the Chief Justice's majority Bicameralism and Presentment Clause analysis in ways similar to Justice Scalia's and Breyer's dissents in Clinton. Much like Justices Scalia and Breyer, who argued that the cancellation power was delegated executive power, ${ }^{236}$ Justice White in Chadha argued that the legislative veto did not constitute "lawmaking."237 Thus, like Scalia and Breyer in Clinton, Justice White concluded that the terms of the two Clauses, which govern law making, said nothing about whether the legislative veto was constitutional. ${ }^{238}$ Like Justices Scalia and Breyer, ${ }^{239}$ White looked to other statutes seemingly incompatible with the Bicameralism and Presentment Clauses that the Court had nonetheless approved to show that a violation could not be found in Chadha. ${ }^{240}$

Unlike the majority in Chadha, which also grounded its holding in the separation of powers and on well-documented evidence that the Presentment Clause was inserted as an all-important check on legislative power, ${ }^{241}$ the majority in Clinton failed to respond to the dissenters in the case convincingly. In addition, it failed to justify its broad interpretation of the Presentment Clause as based on the first purposes of the Clause. For in Clinton, the Line Item Veto Act enhanced the President's ability to make sure that omnibus spending bills were not "oppressive, improvident, or ill-considered measures"242 - the exact ability and executive function the Court in Chadha went so far to defend. Thus, while the Chadha Court effectuated the first purposes of the Presentment Clause by checking the back-door growth of legislative power, the Clinton Court invoked the

233. See supra notes $184-87$ and accompanying text.

234. See supra note 186 and accompanying text.

235. See supra notes 188 and 189 and accompanying text.

236. See supra Part III.A.2.a.

237. See supra note 188 and accompanying text (discussing Justice White's dissent in detail).

238. See INS v. Chadha, 462 U.S. 919,980 (1983) (White, J., dissenting).

239. See supra Part III.A.2.a.

240. See Chadha, 462 U.S. at 986-87 (White, J., dissenting).

241. See supra notes $\mathbf{1 8 4 - 8 9}$ and accompanying text.

242. Chadha, 462 U.S. at $947-48$. 
Presentment Clause where other limits on executive power would appropriately have applied. The next Section argues that the Line Item Veto Act's cancellation power violated the separation of powers and that this was the limit on executive power that should have been controlling in this case. On this view, the Court in Clinton reached the right result, as did the Chadha court, by striking down the legislation in question; however, unlike the Chadha Court, the Clinton Court's Presentment Clause analysis is indefensible. The Court's holding vindicates neither the plain meaning of the Clause's text nor the Clause's original purpose. Rather, it expands the scope of a Clause intended to check Congress's power in order to place limitations on the executive's power. It does so without considering whether additional executive power indeed upsets the balance of power among the three branches or even enhances the values underlying the separation of powers.

\section{B. The Line Item Veto Act and the Separation of Powers}

As noted above, the second question a Court should ask itself in a case such as Clinton is whether the grant of power violates the nondelegation doctrine and whether the exercise of that granted power undermines separation-of-powers values. ${ }^{243}$ In Clinton, Justices Scalia, O'Connor, and Breyer found the delegation of the cancellation power proper. Justices Breyer and Kennedy openly disagreed with one another as to whether placing the cancellation power in the President's hands upset the balance of power among the branches. ${ }^{244}$ This Section examines those conclusions, arguing that while the Line Item Veto Act did not violate the Court's nondelegation doctrine, which is a subset of the Court's separation-of-powers jurisprudence, it did violate the separation of powers generally.

\section{The Cancellation Power and the Court's Nondelegation Doctrine}

As the discussion in Part II.D. 3 above indicates, the Court's nondelegation doctrine lacks teeth. ${ }^{245}$ That said, it has two principal requirements, both of which are easily met. First, Congress cannot delegate its core legislative powers. ${ }^{246}$ As Justice Breyer noted in his dissent in Clinton, Congress has, consistent with the doctrine, permissibly delegated extensive

\footnotetext{
243. See supra Part III, introductory paragraphs.

244. See supra notes 19-20,85-86, and accompanying text.

245. Whether or not the nondelegation doctrine-or the Court's Spending Clause jurisprudencewill enjoy the revival the Commerce Clause did in Lopez is open to debate. See id.; see also Lynn A. Baker, Conditional Federal Spending After Lopez, 95CoLum. L. REv. 1911 (1995). The separation of powers seems less on the Court's agenda than federalism. See supra notes 122-23 and accompanying text.
}

246. See Yakus v. United States, 321 U.S. 414 (1944) (holding that congressional delegation of rule-making power to an executive branch official did not constitute delegation of core legislative power). 
rule-making power both to federal agencies located in the executive branch and to commissions upon which federal judges serve. ${ }^{247}$ For example, the Mistretta Court upheld the judiciary's rule-making power to implement the Federal Sentencing Guidelines. ${ }^{248}$

When compared to Clinton, redirecting specific budgetary provisions pursuant to statutory guidelines seems less like law making than does granting federal judges the power to promulgate the Federal Sentencing Guidelines. The President who chooses to spend line-item money to reduce the deficit based on a preexisting law enabling him to do so does not have the prospective effect of establishing the way federal criminal defendants would be sentenced heretofore, as did the Guidelines. Thus, if the allinclusive, judge-made Federal Sentencing Guidelines comport with the Court's nondelegation doctrine, so too should a presidential line-item veto which has only a limited effect. ${ }^{249}$

The nondelegation doctrine secondly requires that Congress cabin sufficiently the delegate's discretion. As Justice Breyer noted in Clinton, Chief Justice Taft succinctly formulated this second requirement: "[T] Constitution permits only those delegations where Congress 'shall lay down by legislative act an intelligible principle to which the person or body authorized to [act] is directed to conform." 250 As Justice Breyer's dissent in Clinton convincingly argues, the Line Item Veto Act also comports with this second requirement of the nondelegation doctrine. Justice Breyer identified three ways in which the Line Item Veto Act attempts to define the contours of the President's authority to excise budgetary provisions: (1) the "procedural" requirement that the President consider a spending provision's purpose and legislative history; ${ }^{251}$ (2) the "purposive" requirement that cancellations should both promote "greater fiscal responsibility" and "eliminate wasteful federal spending and ... special tax breaks;" "252 and (3) the "substantive" requirement that cancellations help reduce the federal deficit and do not "impair any essential Government functions ... [or] harm the national interest." "253 Although these standards were broad, they are as intelligible, or more so,

247. See Clinton v. New York, 118 S. Ct. 2091, 2123-24 (Breyer, J., dissenting).

248. See Mistretta v. United States, 488 U.S. 361, 427 (1988).

249. See Clinton, 118 S. Ct. at 2118 (Scalia, J., concurring in part and dissenting in part) ("[T]he doctrine of unconstitutional delegation ... is preeminently not a doctrine of technicalities."). After Mistretta v. United States, 488 U.S. 361 (1988)-discussed supra notes 164-68 and accompanying text-anything short of Congress giving one of the "junior-varsity Congress[es]" their letterman's jacket and letting them do all of the House's and Senate's business, it is hard to imagine a delegation running afoul of the core-legislative-power requirement. Id. at 427 (Scalia, J., dissenting).

250. Clinton, 118 S. Ct. at 2125 (Breyer, J., dissenting) (quoting J.W. Hampton, Jr. \& Co. v. United States, 276 U.S. 394, 409 (1928)) (emphasis added by Breyer, J.).

251. Clinton, 118 S. Ct. at 2125 (citing 2 U.S.C. § 691(b) (Supp. 11 1997)).

252. Clinton, 118 S. Ct. at 2 I25 (quoting H.R. CONF. REP. No. 104-491, at 15 (1996)).

253. Clinton, I18 S. Ct. at 2125 (quoting 2 U.S.C. $\$ 691$ (a)(A) (Supp. 11 1997)). 
than standards the Court previously upheld. ${ }^{254}$ Moreover, the cancellation power is "aimed at a discrete problem": three types of spending items which comprise one third of the annual federal budget. ${ }^{255}$ By contrast, the statute that the Schechter Court struck down on nondelegation doctrine grounds was both aimed at all aspects of the national economy, and it created a "roving commission to inquire into evils and upon discovery correct them." 256 In Clinton, the President's powers were far more limited; his discretion was cabined by explicit standards, and he was forced to articulate his reasons for canceling spending items in a "special message" to Congress. ${ }^{257}$ Thus, the delegation of power to cancel spending provisions did not violate the nondelegation doctrine.

As with Commerce Clause jurisprudence until Lopez, the delegation doctrine currently employed by the Court seems an implicit concession to the post-New Deal administrative state. ${ }^{258}$ Therefore, passing its two-part test and falling within the protective umbrella of abundant case law permitting delegation should not be the end of inquiry for those committed to the separation of powers. The next Section argues that if the majority had made this important inquiry, it would have found a separation-of-powers violation.

\section{The Cancellation Power and the Separation of Powers}

As seen above, Justice Kennedy, in concurring with the majority in Clinton, got the Presentment Clause analysis wrong; the Line Item Veto Act did not violate the Clause's finely wrought law-making process. ${ }^{259}$ Justice Kennedy, however, unlike Justice Breyer, got the separation-ofpowers analysis right. Justice Kennedy correctly concluded that the Line Item Veto Act violated the values at the core of the separation-of-powers principle. While Justice Breyer erred in this final portion of his opinion, at least he began by asking the right questions: Justice Breyer asked whether the Line Item Veto Act aggrandized the President's power, encroached upon Congress's power, undermined accountability in government or

254. See Clinton, 118 S. Ct. at 2125-27 (citing several examples).

255. Id. at 2126 .

256. Id. (quoting A.L.A. Schechter Poultry Corp. v. United States, 295 U.S. 495, 551 (1935) (Cardozo, J., concurring)). Moreover, it should be noted, cases decided subsequent to Schechter have upheld enormously broad delegations of power-far broader than the one in Schechter. See, e.g., NBC v. United States, 319 U.S. 190, 225 (1943) (holding that Congress can delegate legislative power to the Federal Communications Commission to regulate radio stations in accordance with the public interest).

257. 2 U.S.C. $\$ 691(\mathrm{a})(3)(\mathrm{B})$.

258. See Donald H. Regan, How to Think About the Federal Commerce Clause and Incidentally' Rewrite United States v. Lopez, $94 \mathrm{MicH}$. L. Rev. 554, 554 (1995) ("On the one hand, we have a collection of doctrinal rules that, if we take them seriously, allow Congress to do anything it wants under the commeree power. On the other hand, we continue to pay lip service to the idea that Congress's power is limited."); see also supra note 245 .

259. See supra Part III.B. 
threatened liberty - the four indicia of a separation-of-powers violation identified in Part II.D of this Comment.

\section{a. The Cancellation Power and the Anti-Aggrandizement Principle}

One indicator of a violation of the separation of powers is an attempt by one branch to aggrandize itself at the expense of a coordinate branch. In Clinton, Justice Breyer first concluded that the Line Item Veto Act did not "aggrandize" the President's power because the grant was "limited to the context of the budget."260 The choice the grant gave the President, to cancel or not to cancel, was a power well-recognized in the analogous nondelegation doctrine cases he cited. ${ }^{261}$ Although the nondelegation cases may hold as much, that does not unsettle the basic notion that the separation of powers encapsulates: Power cannot be concentrated in the hands of one branch of government. ${ }^{262}$ Admittedly, the scope of the modern administrative state makes it hard to argue with Justice Breyer's analysis. If budgetary delegations violate the separation of powers, the more expansive delegations in other fields must violate it even more clearly. If one were to adopt such a hard-line and formalistic stance about the separation-ofpowers, a dismantling of the modern administrative state would necessarily follow, as all delegations to the executive branch arguably aggrandize that branch's power.

Nonetheless, one distinction between the Line Item Veto Act delegations and normal delegations to executive agencies makes the aggrandizement argument more tenable. Unlike most delegations of rule-making power to agencies, granting the President the cancellation power, as in Clinton, is not a grant of power to a diffuse bureaucratic body ${ }^{263}$ Unlike a federal agency that relies on Congress to provide its budget and define its policy objective, the President is not so beholden to Congress when deciding whether to make line-item cancellations. Expanding the President's scope of power thus poses a threat of centralization that grants of power

260. Clinton, 118 S. Ct. at 2125 (Breyer, J., dissenting).

261. See id.

262. Justice Kennedy wrote,

Quoting Montesquieu, The Federalist Papers made the point in the following manner: 'When the legislative and executive powers are united in the same person or body ... there can be no liberty, because apprehensions may arise lest the same monarch or senate should enact tyrannical laws to execute them in a tyrannical manner.'

ld. at 2109 (Kennedy, J., concurring) (quoting The FEDERALIST No. 47, supra note 103, at 303 (James Madison)).

263. Scholars disagree as to what it means to delegate power to the administrative state. Scholars in the Calabresi and Prakasb camp believe in a "unitary" executive, or superintendent President who has plenary executive authority to make sure laws are faithfully administered. See Calabresi \& Prakash, supra note 91, at 664. Scholars such as Lessig and Sunstein take the opposite nonhierarchical position with respect to the President's power, namely that, the agencies exist independent of the executive and can and should administer laws on their own behalf. See Lessig \& Sunstein, supra note 91, at 118-99. 
across and within federal agencies do not. ${ }^{264}$ Additionally, several Supreme Court decisions limiting the President's and enhancing Congress's ability to control administrative officials within the executive branch bolster the claim that a grant of power to federal agencies is different than a grant of power to the President. ${ }^{265}$ It is normally more difficult for the President to take full advantage of the power vested in agencies, whereas in the Line Item Veto Act context he can affect major policy changes simply on his own accord. Therefore, an aggrandizement can be found in the latter case.

The Court should guard against presidential aggrandizement in Clinton as vigilantly as it did in cases such as Bowsher, Buckley, and Metropolitan Airport-cases in which the Court found that similar strengthening unconstitutionally aggrandized Congress's powers. ${ }^{266}$ In those cases, Congress may have aggrandized its own power, whereas in the Line Item Veto Act, Congress aggrandized the President's power. However, the Court should not focus on who is doing the vesting. Rather, it should focus on where the power vests, and whether any checks on that power exist. For instance, in the federal agency context, courts review agency decisions, the President has some degree of power to check improvident agency action, and Congress can wield its power of the purse to check errant administrators. The President, on the other hand, given the ability to choose whether to enforce or cancel certain spending items and tax breaks, is not so checked. Under this Line Item Veto Act scheme, he has extensive, unilateral power over national policy making ${ }^{267}$ _even though it can be overridden by a congressional disapproval bill-that the Framers rightly protected against.

Although the aggrandizement factor is not dispositive in Clinton given the nature of the administrative state, it surely weighs in favor of finding a separation-of-powers violation. Indeed, this factor should not be ignored or dismissed simply because it is not as obvious an indicator of a violation as it was in the Steel Seizure case, for example. ${ }^{268}$

264. Compare supra note 263, and the Calabresi \& Prakash position, which would hold that any grant of power to the administrative state is a grant of power to the President as "unitary" executive. See Calabresi \& Prakash, supra note 91, at 664.

265. See, e.g., Morrison v. Olson, 487 U.S. 654, 691 (1988) (holding that Congress may limit the President's ability to remove even purely executive officers if removal restrictions are not "of such a nature that they impede the President's ability to perform his constitutional duty"); Wiener v. United States, 357 U.S. 349 (1958) (holding that the President may not remove member of War Claims Commission because Congress had not explicitly conferred the right to do so); Humphrey's Executor v. United States, 295 U.S. 602 (1935) (holding that Congress could place limits on the President's ability to remove members of the Federal Trade Commission).

266. See supra notes 143-45 and accompanying text.

267. See infra text accompanying note 275 .

268. See supra note 141-42 and accompanying text. 


\section{b. The Cancellation Power and the Anti-Encroachment Principle}

Just as the line-item veto arguably aggrandizes the executive at the expense of the Congress, so too does it impermissibly put the executive in a law-making role. In Clinton, Justice Breyer wrongly rejected this conclusion. He concluded that the Line Item Veto Act did not encroach upon Congress's power. He reasoned that Congress retained the power, "by simple majority": (1) to exempt future appropriations bills and any of their sections or provisions from the President's cancellation power; ${ }^{269}$ (2) to "'disapprov[e],' and thereby reinstate, any of the President's cancellations",270 and (3) to "draft[] and enact[] the appropriations statutes that are subject to the Act in the first place."271 Therefore, Justice Breyer argued, only the same "legislative inertia" that normally prevents Congress from enacting a bill would prevent it from making an appropriation which the President seeks to cancel. As such, there was no encroachment.

Justice Breyer's argument, however, seems to ignore realpolitik concerns. First, if the Line Item Veto Act normally gives the President the power to cancel line items in appropriations statutes, the President might be tempted to veto any bill that exempts itself or any of its provisions from his cancellation power. National public sentiment would potentially support such a move because the President would be able to make the argument that Congress was shielding the bill from "pork-trimining." In response to this veto carrying popular support, Congress would be able to deny the President's new cancellation power only by a two-thirds, and not a simple, majority. Therein lies the encroachment.

Second, congressional law-making is usually a game of trade-offs..$^{272}$ Although these trade-offs may result in inefficiencies, if the President can easily cancel one-half of any bargain and then veto a resulting disapproval resolution, members of Congress who fear that the President will cancel their projects, or bargaining chits, may not be so willing to make the deals necessary to enact legislation. ${ }^{273}$ And while this result might be positive in terms of policy and please those interested in a leaner federal government, this scheme surely encroaches upon the way Congress has done its business since the founding.

Again, even though Congress invited this encroachment on its power, it still poses constitutional problems. A weakened Congress, like a

\footnotetext{
269. Clinton, 118 S. Ct. at 2124 (Breyer, J., dissenting).

270. Id. (quoting 2 U.S.C. \$ 691b(a) (Supp. II 1997)).

271. Id.

272. See James E. Anderson, Public Policymaking 141-44 (2d ed. 1994) (describing the onefor-one bargains legislators often make in order to garner votes for specific bills).

273. See, e.g., Jefrrey H. Birnbaum \& Alan S. Murray, Showdown at Gucci Gulch: LaWMaKERS, LOBBYISTS, AND THE UNLIKELY TRIUMPH OF TAX ReFORM 204-33, 253-80, 284-89 (stressing the important role trade-offs played in enacting the Tax Reform Act of 1986, but suggesting that the trade-offs somewhat undermined efficacy of legislation).
} 
weakened President (in Myers and Morrison) or a weakened Court (in City of Boerne and the Correspondence of the Justices), threatens liberty. ${ }^{274}$ As Justice Kennedy observed, the fact that the 104th Congress "surrendered its authority by its own hand ... does not make [the cession of power] innocuous. The Constitution is a compact enduring for more than our time, and one Congress cannot yield up its own powers, much less those of other Congresses to follow."275 For these reasons, although again not dispositive, the anti-encroachment factor heavily weighs in favor of finding a separation-of-powers violation.

\section{c. The Cancellation Power and Accountability}

The cancellation power undermines government accountability. Justice Breyer similarly underestimated the import of this third indicia of a separation-of-powers violation. He argued that the Line Item Veto Act's language was "sufficient to provide the President, and the public, with a fairly clear idea as to what Congress had in mind. And the public [could] judge the merits of the President's choices accordingly."276 Accordingly, the public would know if the President acted imprudently or discriminatorily and it could pressure the President to comply with the standards that Congress set forth.

The first problem with this argument goes to one of the main purposes for the line-item veto. As mentioned above, one argument advanced in favor of the line-item veto power was that the President's national office would shield him from the localism that works so destructively in Congress. ${ }^{277}$ Indeed, the Act itself speaks of protecting the national interest. ${ }^{278}$ The best check on government that citizens retain, however, remains

274. See supra notes $146-55$ and accompanying text.

275. Clinton, $118 \mathrm{~S}$. Ct. at 2109 (Kennedy, J., concurring). Because Congress possesses the power of the purse, it is often called the most dangerous branch, as compared to the Court, which Hamilton called the least dangerous. Cf. THE FEDERALIST No. 78, at 465 (Alexander Hamilton) (Clinton Rossiter ed., 1961) (coining the phrase the "least dangerous" branch), with THE FEDERALIST No. 48, at 309 (James Madison) (Clinton Rossiter ed., 1961) ("The legislative department is everywhere extending the sphere of its activity and drawing all power into its impetuous vortex."). Scholars who discuss "aggrandizement" and "encroachment" as evincing separation-of-powers violations often limit their discussions to congressional encroaching or aggrandizing. See Froomkin, supra note 134, at 1367-68. In this case, however, the aggrandizement and encroachment threatens liberty even though Congress is the "victim." Because Congress remains the most accountable branch of government to the citizenry, to the extent it cedes power to the President and dilutes the public's ability to act as a check on govemment, see Brown, supra note 100 , at 535-38, 570-77, it invites tyranny. See supra Part Ill.B.2.cd; see also infra notes 277-79 and accompanying text. Moreover, for scholars such as Martin S. Flaherty, who believe that the unitary executive has seized more power in recent constitutional history, the balance of powers in government "is ill served by a device through which Congress not only gives away significant power, but gives it away directly to the President rather than to subordinate departments or agencies." Flaherty, supra note 120, at 1725, 1838 (discussing the line-item veto).

276. Id. at 2127 (Breyer, J., dissenting).

277. See supra note 38 and accompanying text.

278. See 2 U.S.C. $\$ 691$ (a)(3)(1) (Supp. II 1997). 
their ability to apply pressure on their representatives in Congress, over whom they have more direct control. Citizens in a district can vote out of office a representative who consistently ignores their needs. Citizens residing in a state that does not hold a large number of electoral college votes can do little on election day to a President who cancels spending items benefiting their state but does not cancel spending items benefiting more populous states. Understood this way, the Line Item Veto Act upsets the separation of powers along its "vertical axis," that is, "between each branch and the citizens in whose interest powers must be exercised."279 That Congress cannot help but spend money irresponsibly or govern irrationally is its own fault. As with other attempts at unconstitutional term-limit reform, ${ }^{281}$ however, if citizens want a more responsible government, they must vote more responsibly instead of tinkering with the structure of government that secures their liberty. ${ }^{281}$ Although the President often does promote the national interest in exercising his Article I veto power, the cancellation power allows him to play favorites as we fear his colleagues in Congress do, but without the iinmediate check at the local congressional district voting booth.

The second accountability problem with granting the President cancellation power is that it encourages parochialisin. If the President has the line-item veto power, Congress can argue that it is the President's job to protect national interests while it is Congress's job to promote local ones. Congress was created to pursue an agenda informed by a greater sense of national purpose, not the factionalism and provincialism that debilitated the states under the Articles of Confederation. ${ }^{282}$ Moreover, as with the "junior-varsity Congress" created in Mistretta, ${ }^{283}$ the Line Item Veto Act allows members of Congress to skirt difficult policy issues. ${ }^{284}$ Rather than

279. Clinton, 118 S. Ct. at 2110 (Kennedy, J., concurring). Rebecca Brown speaks of "[r]etaliation at the ballot box for a representative's violation of the public trust" as a means to "secure liberty," albeit a "crude ... blunt instrument ...." Brown, supra note 100, at 571 . However crude and blunt, this check still serves an important function and should not be diluted further. "Electoral responsibility is a means for meting out consequences for violations of public trust, for ferreting out corruption, and for limiting entrenchments and accretion of excessive power over time-transgressions that ultimately threaten the liberty of the people." Id. at 570-71 (citations omitted).

280. See U.S. Term Limits, Inc. v. Thomton, 514 U.S. 779 (1995) (invalidating Arkansas Term Limitation Amendment, which prolibited U.S. Representatives from serving more than three terms and U.S. Senators from serving more than two).

281. Justice Kennedy writes: "Failure of political will does not justify unconstitutional remedies." Clinton. 118 S. Ct. at 2108 (Kennedy, J., concurring). "The Framers of the Constitution could not command statesmanship. They could simply provide structures from which it might emerge." Id. at 2110. The fact that federalisin, the separation of powers, and a government designed to be responsible to the electorate "are not employed, or that they prove insufficient, cannot validate an otherwise unconstitutional device." Id.

282. See Cass R. Sunstein, Interest Groups in American Public Law, 38 Stan. L. Rev. 29, 3I-44 (1985); see also RAKOVE, supra note 39, at 190.

283. Mistretta v. United States, 488 U.S. 361, 427 (1988) (Scalia, J., dissenting).

284. See supra notes $163-68$ and accompanying text. 
make the difficult decisions to cut politically popular but irresponsible spending projects, Congress placed the burden on the President to act for the good of the country. ${ }^{285}$

Third, in addition to congressional statutory guidelines, executive agencies exercising power delegated from Congress usually promulgate rules that elaborate on those general guidelines. "Doing so," Justice Breyer observed, "diminishes the risk that the agency will use the breadth of a grant of authority as a cloak for unreasonable or unfair implementation."286 President Clinton did not promulgate any such rules, nor did the Line Item Veto Act require him to do so. Absent these requirements, citizens had a diminished ability to scrutinize the President's cancellations and accordingly hold him accountable for them.

Fourth, agency decisions are typically subject to judicial review. The courts provide citizens with an important venue to protect themselves against abuses of executive power. ${ }^{287}$ Justice Breyer argued that such a forum was not necessary under the Line Item Veto Act because presidents, unlike agency decision makers, are popularly elected. Moreover, he argued, the courts usually treat presidential executive decisions with greater deference. ${ }^{288}$ Although both his retorts partially mollify some accountability concerns, the fact remains that the Line Item Veto Act stifles citizen participation in government. In sum, the value of preserving accountability tips in favor of finding a separation-of-powers violation in Clinton.

\section{d. The Cancellation Power and Liberty}

The fourth indicator of a separation of powers violation is whether the grant or exercise of power violates liberty. In Clinton, Justice Breyer dismissed concerns about liberty, instead advancing the functionalist argument, favored by Justice White, that the Court should interpret the Constitution's structural limitations "generously" and "nonliteral[ly] ... in light of the need for 'workable govemment."'289

285. See supra note 42 and accompanying text. The argument articulated in this paragraph could be misused to argue against the constitutionality of all administrative agencies. Although many agency structures and practices pose interesting constitutional questions beyond the scope of this Comment, for reasons mentioned elsewhere, see supra notes 263-67 and accompanying text; infra notes 293-98 and accompanying text, the President's exercise of power under the Line item Veto Act poses problems different in kind than those posed by agencies generally.

286. Clinton, 118 U.S. at 2128 (Breyer, J., dissenting).

287. See Part I1.C supra; see also Brown, supra note 100, at 571.

288. See Clinton, 118 U.S. at 2128 (Breyer, J., dissenting).

289. Id. at $2 \mathrm{I} 19,2120$ (Breyer, J., dissenting) (quoting Youngstown Sheet \& Tube Co. v. Sawyer, 343 U.S. 579, 635 (1952) (Jackson, J., concurring)). In Bowsher v. Synar, Justice White had invoked the rhetoric of functionalism. See 478 U.S. 714, 774 (1986) (White, J., dissenting) ("Realistic consideration ... reveals that the threat to separation of powers conjured up by the majority is wholly chimerical."); id. at 776 ("The majority's reliance upon 'rigid dogma' and 'an unyielding principle to strike down a statute posing no real danger of aggrandizement of congressional power is extremely 
Justice Kennedy responded to Justice Breyer by describing a threat to liberty:

The principal object of the statute, it is true, was not to enhance the President's power to reward one group and punish another, to help one set of taxpayers and hurt another, to favor one State and ignore another. Yet these are its undeniable effects. The law establishes a new mechanism which gives the President the sole ability to hurt a group that is a visible target, in order to disfavor the group or to extract further concessions from Congress. ${ }^{290}$

Courts and judges should not so easily dismiss the consequentialist, parade-of-horribles argument that Justice Kennedy invoked here (and that Scalia employed in Morrison and Mistretta). The purpose for separating the powers among the branches was the assumption that if given power, political actors would abuse it. ${ }^{291}$ As has unfortunately been the case with the Independent Counsel, grave predictions about abuses of power often come true. ${ }^{292}$ We need not fear the same grave consequences with the Line Item Veto Act, because the majority correctly (if for the wrong reasons) struck it down. Nonetheless, courts should not go the way of Justices White and Breyer in discounting the real possibility of abuses of power.

In Clinton, as in Morrison and Mistretta, the most important indication of a separation-of-powers violation was present: a foreseeable threat to liberty. Because all four indicia in this case pointed in the direction of a violation, the Lime Item Veto Act should have been struck down as a violation of the separation-of-powers principle. The next Section briefly speculates why it was not and argues why it should have been.

\section{The Court's Rhetoric in Clinton}

One can only speculate as to why the Court reached the decision it did, for the reasons it did, in Clinton. No clear conservative-liberal split explains the voting line-up or the result. Nor can one explain why the majority chose to rely on the Presentment Clause and Chadha to invalidate the Line Item Veto Act when these touchstones seem directed at limiting congressional, not executive, power. Perhaps Justice Scalia correctly surmised that "[t]he title of the Line Item Veto Act . . . succeeded in faking out the Supreme Court."293

\footnotetext{
misguided and insensitive to our constitutional role."); see also supra note 126 and accompanying text (discussing Justice White's functionalist approach). Using this metoric of functionalism, Justice Breyer argued that since the President's power under the Line ltem Veto Act was limited, the risk of "widespread ... arbitrary Presidential decisionmaking" was diminished. Clinton, $118 \mathrm{~S}$. Ct. at 2130 (Breyer, J., dissenting). And since that potential was diminished, the Court should not "referee a dispute among [sic] the other two branches" of government. Id. at 2119.

290. Clinton, 118 S. Ct. at 2109 (Kennedy, J., concurring) (emphasis added).

291. See supra note $110-11$ and accompanying text.

292. See supra notes 8 and 10 and accompanying text.

293. Clinton, 118 S. Ct. at 2118 (Scalia. J., concurring in part and dissenting iu part).
} 
Extrapolations from certain scholars' writings cast a more sympathetic light on the Court's reasoning. The Court's thinking may resemble that in Chadha or Lopez. One scholar argues that in Chadha, the Court sought to force Congress to take responsibility for its parochialism rather than allowing it to abdicate its authority and responsibility to executive agencies. In Chadha, the Court invalidated the legislative veto, a power that allowed Congress to shirk many of its difficult law-making duties by delegating to agencies with the knowledge that it could always void agency actions. ${ }^{294}$ Likewise, the Clinton Court can be seen as forcing Congress to take responsibility for parochial pork-barreling, rather than allowing the legislature to insulate itself from accountability by shifting responsibility and the attendant criticism to the President. Rather than saying explicitly that it was doing these things and offending Congress, the Court arguably grounded its Clinton and Chadha holdings on the vague text of the Presentment Clause.

The Court's more deferential rhetoric is also apparent in Lopez. Judge Louis Pollak notes that in Lopez, ${ }^{295}$ the Court drew a new line in the sand with respect to the reckless creation of federal power that affects areas of state concern. ${ }^{296}$ In that case, the Court invalidated a statute on Commerce Clause grounds for the first time in sixty years because Congress provided no findings as to why guns near schools affect interstate commerce. ${ }^{297} \mathrm{On}$ this reading, the Lopez statute was unconstitutional not because of its substantive provisions, but because Congress did not adequately go through the process of explaining why the statute comported with the Commerce Clause. Similarly, the Clinton Court could be seen as drawing another new line in the sand. Even though the nondelegation doctrine will not invalidate the Line Item Veto Act, the Court will not permit Congress to give the President the power and the duty to make the hard decisions to cut excess budget and tax credit items. Again, the Court is not holding that the statutory scheme is inherently unconstitutional, but that Congress must do its job more carefully.

Neither of these explanations, however, is entirely satisfactory. They explain the outcome instead of the reasoning and provide too little

294. See supra notes 173-74 (discussing Professor Mendelson's reading of Chadha).

295. United States v. Lopez, 514 U.S. 549 (1995).

296. See Judge Louis H. Pollak, Foreword to Symposium, Reflections on United States v. Lopez, 94 Mich. L. Rev. 533 (1995). Judge Pollak argues that while Lopez will not "downsize the Commerce Clause," the case will mean that other federal statutes will run afoul of its dictates. Id. at 551. He further suggests,

[T] the extent that happens ... such casualties will be attributable not to a restless activism on the part of the Justices but to irresponsibility on the part of a Congress that has failed to make out even a minimally plausible case for utilizing the commerce power to undergird a new regulatory scheme, especially one that deals with problems historically regarded as chiefly of state and local concern.

Id. at 551,552 .

297. See id. at 547,552 (discussing the Court's holding in Lopez). 
guidance for future legislation. The Court could have struck down the Line Item Veto Act by relying on the straightforward separation-of-powers analysis it employed in Chadha, or it could have revised the nondelegation doctrine explicitly. Such explicit holdings would temper speculation as to the Court's motives and allow for more reasoned law making in response.

One can imagine, however, why the Court left its holding grounded in the pliant text of the Presentment Clause. Reinvigorating the nondelegation doctrine might mean striking down scores of federal statutes that vest rulemaking power in the current multitude of federal agencies. A separationof-powers analysis that does not distinguish between aggrandizement of power in the President and in the rest of the executive branch, similarly, might compel the same result. ${ }^{298}$

But Justice Kennedy's approach in addressing the separation-ofpowers concerns at issue in Clinton was far more reasonable than that. He focused on the power the line-item veto gave the President, not aggrandizements of executive power generally. In discussing the President's power, Kennedy was able to identify the threats to liberty that the Act posed. And in identifying these threats he was able to show how the Act contradicted the original political theory upon which our trifurcated government rests. In employing this logic and not relying on a nonexistent Presentment Clause violation, he explicitly vindicated these principles. While an explicit separation-of-powers analysis was not crucial to the result in Clinton, if these values had been fully exposed in cases like Morrison and Mistretta, we might not have to live with the possible threats to liberty that the regimes they create invite. Rhetoric thus matters, and the Court should address separation-of-powers questions squarely, instead of stretching the Constitution's text, when it deems appropriate, to answer these questions.

\section{CONCLUSION}

In Clinton, the majority wrongly rested its decision on a textual violation that did not exist. President Clinton did not literally or technically rewrite, repeal, or amend the Taxpayer Relief Act or the Balanced Budget Act. Nor did he exercise a new veto power as the title of the Line Item Veto Act deceptively suggests. President Clinton performed his Article II duty and faithfully executed the law, as it was codified in the Line Item Veto Act and later-enacted statutes referencing it. ${ }^{299}$ Therefore, the Act did not violate the Presentment Clause or upset the delicate law-making process it prescribes. As a professor who may wish to remain nameless

298. $C f$. notes $263-67,285-88$, and accompanying text (discussing the separation-of-powers difference between vestments of power to the President and to executive agencies).

299. See supra Part III.A; see also Prakash, supra note 21, at 38-42. 
jokingly suggested, only two former administrative law professors-Scalia at Chicago and Breyer at Harvard-could see this difference.

What remains surprising is that Justice Scalia-the most ardent defender of the separation of powers ${ }^{300}$-did not pounce on the separation-of-powers violation imherent in the Line Item Veto Act. ${ }^{301}$ When one considers that federalism and the separation-of-power principles serve the same end-the security of liberty under government ${ }^{302}$ - perhaps it is unsurprising that a Justice best known for his vigilant defenses of federalism spotted the separation-of-powers infirmity in the Act. ${ }^{303}$ Although no one on the Court joined his concurrence, Justice Kennedy's separation-ofpowers analysis rightly championed liberty over efficiency.

This Comment argues the Court should decide future separation-ofpowers cases by returning to the first principles that both Justice Scalia in his famous dissents in Morrison and Mistretta, and Justice Kennedy in his concurrence in Clinton identified and championed. This straightforward approach to separation-of-powers issues not only better educates the Court's audience, but it also allows the Court to weigh the rebalancing of power at issue to better determine whether underlying liberty interests are jeopardized. If liberty interests are jeopardized, the statute can be struck down on first principle grounds; if they are not, the Court should allow government to operate as efficiently as possible in our intentionally inefficient system.

300. See Autumn Fox \& Stephen T. McAllister, An Eagle Soaring: The Jurisprudence of Justice Antonin Scalia, 19 CAMPBELl L. REv. 223, 242-44 (1997).

301. Perhaps it was Justice Scalia's belief in a strong, unitary executive that led him to believe a shift in power toward the executive posed no problem. See Calabresi \& Prakash, supra note 91, at 546 (discussing Justice Scalia's support of a strong executive, as a matter of original understanding).

That Justice Breyer did not find a separation-of-powers violation is not surprising. Justice Breyer is one of the most eloquent advocates of scientific and rational administrative regulation. A true believer in functionalism, see, e.g., Clinton 118 S. Ct. 21 19, 2123 (Breyer, J., dissenting), and the "several virtues inherent in many administrative systems: rationalization, expertise, insulation, and authority," Stephen G. Breyer, Breaking the Vicious Circle 61 (1993), Justice Breyer was the "guiding force" behind the final draft of the Federal Sentencing Guidelines, STIrH \& CaBRANES, supra note 11, at 58. which the Court upheld in Mistretta.

302. See Brown, supra note 100 , at 535; see also supra note 113.

303. See Professor Jesse H. Choper, Lecture at School of Law. University of California, Berkeley (Boalt Hall) (Aug. 25, 1998) (describing Justice Kennedy's jurisprudence and reputation). 